\title{
Recent advances in the search of BCRP- and dual P-gp/BCRP-based multidrug resistance modulators
}

\author{
Silvia Dei, Laura Braconi, Maria Novella Romanelli, Elisabetta Teodori \\ Department of Neuroscience, Psychology, Drug Research and Child's Health - Section of Pharmaceutical and Nutraceutical \\ Sciences, University of Florence, via Ugo Schiff 6, Sesto Fiorentino (FI) 50019, Italy. \\ Correspondence to: Prof. Silvia Dei, Elisabetta Teodori, Department of Neuroscience, Psychology, Drug Research and Child's \\ Health - Section of Pharmaceutical and Nutraceutical Sciences, University of Florence, via Ugo Schiff 6, Sesto Fiorentino (FI) \\ 50019, Italy.E-mail: silvia.dei@unifi.it; elisabetta.teodori@unifi.it
}

\begin{abstract}
How to cite this article: Dei S, Braconi L, Romanelli MN, Teodori E. Recent advances in the search of BCRP- and dual P-gP/BCRPbased multidrug resistance modulators. Cancer Drug Resist2019;2:710-43. http://dx.doi.org/10.20517/cdr.2019.31
\end{abstract}

Received: 18 Apr 2019 First Decision: 29 May 2019 Revised: 3 Jun 2019 Accepted: 13 Jun 2019 Published: 19 Sep 2019

Science Editor: Helen M. Coley Copy Editor: Han-juan Zhang Production Editor: Huan-Liang Wu

\begin{abstract}
The development of multidrug resistance (MDR) is one of the major challenges to the success of chemotherapy treatment of cancer. This phenomenon is often associated with the overexpression of the ATP-binding cassette $(A B C)$ transporters P-gp (P-glycoprotein, $A B C B 1)$, multidrug resistance-associated protein $1, A B C C 1$ and breast cancer resistance protein, $A B C G 2$ ( $B C R P)$. These transporters are constitutively expressed in many tissues playing relevant protective roles by the regulation of the permeability of biological membranes, but they are also overexpressed in malignant tissues. P-gp is the first efflux transporter discovered to be involved in cancer drug resistance, and over the years, inhibitors of this pump have been disclosed to administer them in combination with chemotherapeutic agents. Three generations of inhibitors of P-gp have been examined in preclinical and clinical studies; however, these trials have largely failed to demonstrate that coadministration of pump inhibitors elicits an improvement in therapeutic efficacy of antitumor agents, although some of the latest compounds show better results. Therefore, new and innovative strategies, such as the fallback to natural products and the discover of dual activity ligands emerged as new perspectives. $B C R P$ is the most recently $A B C$ protein identified to be involved in multidrug resistance. It is overexpressed in several haematological and solid tumours together with P-gp, threatening the therapeutic effectiveness of different chemotherapeutic drugs. The chemistry of recently described BCRP inhibitors and dual P-gp/BCRP inhibitors, as well as their preliminary pharmacological evaluation are discussed, and the most recent advances concerning these kinds of MDR modulators are reviewed.
\end{abstract}

Keywords: Cancer, multidrug resistance, multidrug resistance modulators, ATP-binding cassette transporter inhibitors, P-glycoprotein, multidrug resistance-associated proteins, breast cancer resistance protein

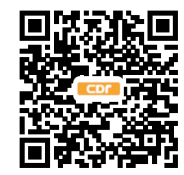




\section{INTRODUCTION}

The resistance of cancer cells to antineoplastic agents represents a substantial limitation to effective chemotherapy. This chemotherapeutic failure can be produced both by intrinsic and acquired resistance. Intrinsic or primary drug resistance occurs among malignant tumor cells which present some inherent characteristics of resistance to anticancer drugs since the beginning of therapy. This kind of resistance can be present also in a small population of tumor cells such as the cancer stem cells ${ }^{[1]}$. Acquired or secondary drug resistance instead is developed during treatment of tumors that were initially sensitive to drug treatment ${ }^{[2]}$. As an example, non-small cell lung cancer or pancreatic cancer are intrinsically resistant to anticancer drugs, while in breast cancer and leukemia, drug resistance can be acquired after treatment with drugs to which the cells were originally sensitive ${ }^{[3]}$.

Multidrug resistance (MDR) is a kind of acquired drug resistance of cancer cells, but also microorganisms, to a variety of chemotherapeutic drugs that are structurally and mechanistically unrelated ${ }^{[4,5]}$, even to drugs to which they have not been exposed previously ${ }^{[6]}$. Once MDR is acquired, the anti-cancer effects of chemotherapeutic drugs decrease. Cancer cells that are originally sensitive to a single anti-cancer drug later become resistant to multiple anti-cancer drugs.

MDR is a complex phenomenon that can result from several unrelated biochemical mechanisms, such as increased drug efflux and decreased drug influx, but also sequestration of anticancer drugs in lysosomes as well as in intracellular organelles and intercellular vesicles, drug inactivation or lack of activation, increased drug metabolism or detoxification, mutations in drug target, activation of survival responses, evasion of apoptosis, cancer stem cell regulation, miRNA regulation, hypoxia induction, increased DNA repair and epigenetic changes ${ }^{[7-11]}$. Some of these mechanisms may coexist, rendering the cell refractory to treatment with drugs acting on a single target.

The MDR phenotype is often linked to the overexpression of transmembrane efflux transporters. In fact, the most widely implicated and studied mechanism of MDR is that resulting from altered cell membrane transport ${ }^{[12]}$. This kind of MDR is due to a lower intracellular drug concentration, associated with accelerated efflux of the chemotherapeutic drug as a consequence of the overexpression of a number of integral membrane transporters that act as extrusion pumps. Several families of efflux pumps, that can use a variety of energy sources, are present in mammals and micro-organisms ${ }^{[5,13]}$. Among these, the most important and best characterized family in humans is the ATP-binding cassette (ABC) superfamily of efflux transporters, that use ATP as energy source ${ }^{[14-16]}$. Overexpression of ABC transporters, frequently detected in human solid and hematologic cancers, is a marker for drug resistance and decreased patient survival ${ }^{[17]}$; moreover, high levels of $\mathrm{ABC}$ transporters can be found also in cancer stem cells ${ }^{[18]}$.

The human $\mathrm{ABC}$ transporters consist of 49 members that are classified into seven subfamilies designated $A B C-A$ to $A B C-G$ according to the similarity of their amino acid sequences ${ }^{[19]}$. These proteins are overexpressed in cancer cells, but they are also present in several important tissues where they play a physiological role. In fact, they have been found in the epithelium cells at blood-brain barrier (BBB), the intestinal epithelium, the biliary canalicular membrane of hepatocytes and the proximal tubules of kidney, where they catalyze the transport of a large variety of structurally diverse compounds across cellular membranes by regulating the secretion of lipophilic molecules and the extrusion of xenobiotics that entered the organism ${ }^{[20,21]}$. Some ABC transporters are also responsible for the homeostasis of endogenous agents, and people carrying defected $\mathrm{ABC}$ genes may be more susceptible to specific diseases such as the Tangier's disease, Stargardt's disease, cystic fibrosis and adrenoleukodystrophy ${ }^{[22,23]}$.

The most important and best-known transporters belonging to the ATP-Binding Cassette superfamily in humans are $\mathrm{P}$-glycoprotein $(\mathrm{P} \text {-gp/MDR1/ABCB1 })^{[24-26]}$, multidrug resistance protein 1 (MRP1/ABCC1 $)^{[27,28]}$ and breast cancer resistant protein (BCRP/ABCG2/MXR) $)^{[29-31]}$. 
These three proteins, as it is for most ABC transporters, are composed of two domains: the transmembrane domain (TMD) and the nucleotide binding domain (NBD), which binds ATP. The NBD is located within cytoplasm; ATP binding and hydrolysis supply the energy for the transport of substrates across the membrane ${ }^{[32]}$. The TMD instead crosses the membrane and is composed of a number of transmembrane sequences, putative alfa-helices, separated by hydrophilic loops. The hydrophobic TMDs recognize and translocate a broad variety of substrates upon conformational changes, determining the characteristics of transported substrates. In Figure 1, the secondary structures of the $\mathrm{ABC}$ family drug transporters P-gp, MRP1 and BCRP are depicted.

Since the carriers must pump transported substrates against a chemical gradient, ATP hydrolysis represents the driving force, and the transmembrane domain must switch between outward- and inward-facing conformations, a mechanism already suggested by Jardetzky ${ }^{[34]}$ in 1966. The conformational switch of the membrane domain which is responsible for the alternating opening is driven by the binding of transport substrate and ATP magnesium salt, followed by ATP hydrolysis.

Several models have been proposed for the efflux mechanism, as the "alternating site" model ${ }^{[35]}$, the "switch" $\operatorname{model}^{[36]}$, and the "constant contact" model ${ }^{[37]}$, based on the biochemical and structural data obtained by multidrug resistance pumps of prokaryotes (Sav1866 from Staphylococcus aureus ${ }^{[38]}$, MsbA in gram-negative bacteria ${ }^{[39]}$ ) and eukaryotes $\left(\mathrm{P}^{-g p^{[40,41]}}, \mathrm{MRP}^{[42]}\right.$ and $\left.\mathrm{TAP}^{[43]}\right)$. Although these models differ with respect to some of the details of the mechanism, they share some essential steps, such as ATP-dependent NBD dimerization and the switching of the TMD between outward- and inward-facing conformations.

Drug translocation starts from the "apo" or ground state of the transporter; the first steps include substrate binding to the TMD and Mg-ATP binding (two molecules) to the NBDs. Substrates seem to bind at the high-affinity site within the TMDs, even if there can be changes of transporter structures at different stages. These bonds induce NBD dimerization and formation of the so called "ATP sandwich", and the switch of the TMDs from the high-affinity inward conformation to the low-affinity outward conformation ${ }^{[44,45]}$, which releases the substrate out of the cell ${ }^{[46]}$. ATP hydrolysis and ADP/Pi release elicit NBD dissociation and reset the ground state of the transporter for the next cycle. Details and order of the steps depend, to some extent, on the transporter type; more information can be found in the paper by Wilkens ${ }^{[4]}$. In Figure 2 a scheme of the mechanism of $\mathrm{ABC}$ exporters is reported.

P-gp/ABCB1/MDR1, a $170 \mathrm{kDa}$ glycoprotein, was the first $\mathrm{ABC}$ efflux transporter found to be responsible for the sensitivity of cells to chemotherapeutic agents ${ }^{[48]}$. P-gp isoforms are encoded by a small family of closelyrelated genes in humans (MDR1, MDR2/3) ${ }^{[49]}$, although only MDR1 is involved in multidrug resistance ${ }^{[50]}$. Human MDR1 is expressed as a single polypeptide consisting of 1280 amino acid residues that are organised in two domains of 610 amino acids, joined by a short 60 aa segment termed the linker region ${ }^{[51,52]}$. As most ABC efflux transporters, P-glycoprotein consists of two N-terminal TMDs and two C-terminal NBDs; each TMD contains six transmembrane segments (-helices). P-gp transports neutral and positively charged molecules: amphipathic compounds both in their unmodified form and as conjugates, lipid soluble compounds (molecular weights in the range of 300 to 1000) and compounds with aromatic rings and a positive charge at physiological $\mathrm{pH}^{[53]}$. On theses bases, it is clear that P-gp can transport many endogenous compounds such as steroid hormones, lipids, peptides and small cytokines ${ }^{[54]}$, but also a broad range of therapeutic drugs including anticancer drugs (e.g., vinca alkaloids, anthracyclines and taxanes), analgesics, antihistamines, antibiotics, antivirals, cardiac glycosides, calcium-channel blockers, calmodulin inhibitors and immunosuppressive agents ${ }^{[5,56]}$.

The second member of ABC efflux transporter revealed to confer MDR was MRP1/ABCC ${ }^{[57,58]}$, which was over-expressed in cancer cells whose P-gp levels were not increased ${ }^{[59,60]}$. MRP1, a 190-kDa glycosylated 
P-gp, ABCB1

MRP1, ABCC1
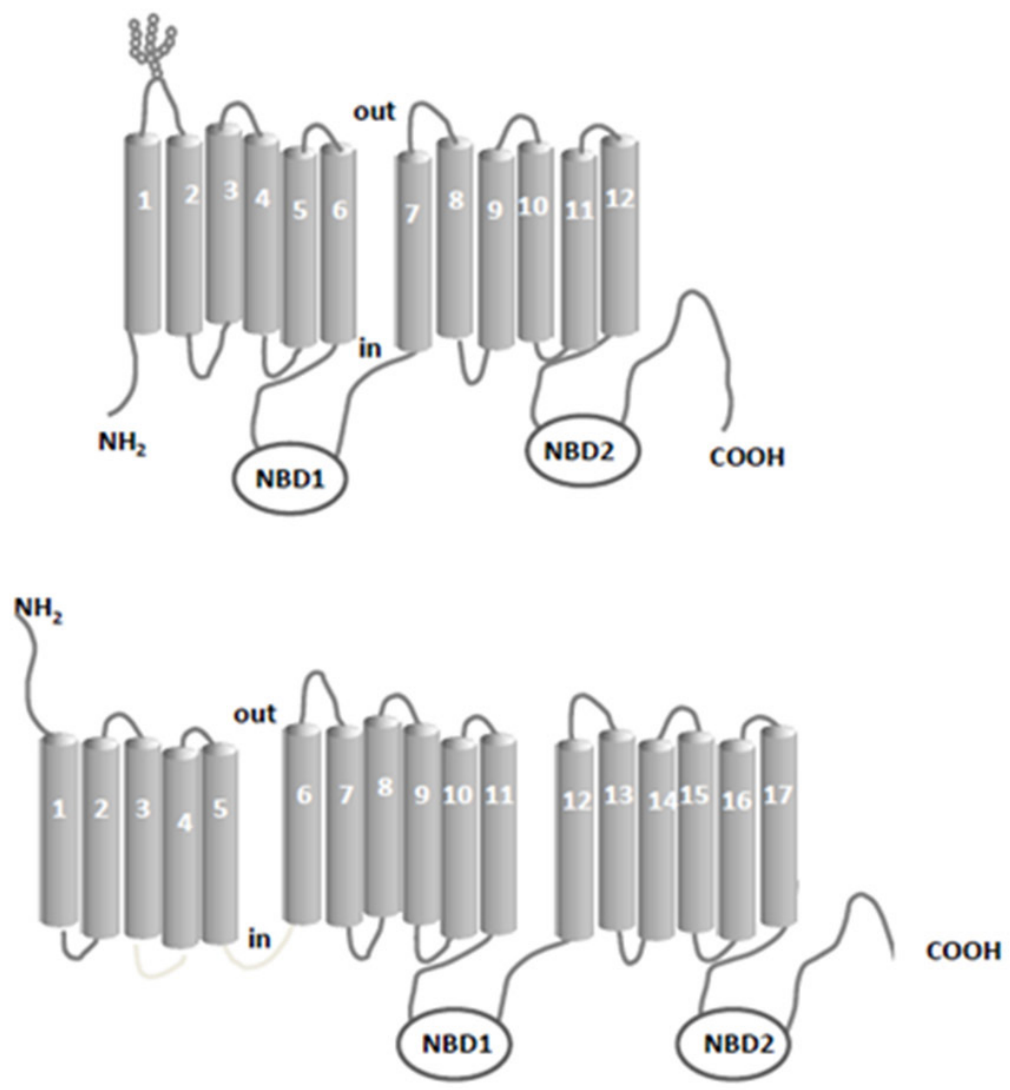

BCRP, ABCG2

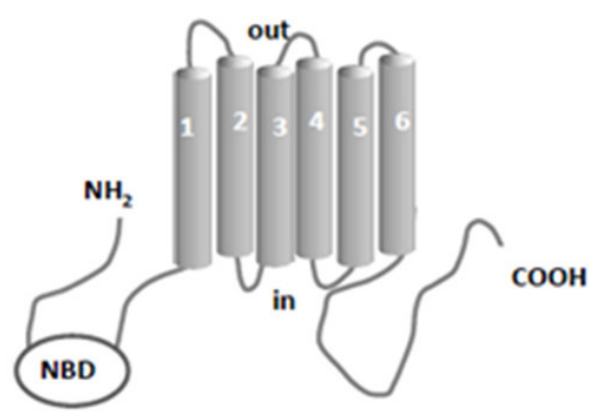

Figure 1. Schematic picture of the secondary structure of the ABC family drug transporters P-gp, MRP1 and BCRP. NBD: nucleotide binding domains

polypeptide, is constituted by 1531 amino acids and is composed of three TMDs (17 transmembrane helices), two NBDs and one intracellular linker region. Like P-gp, MRP1 can confer the resistance to many chemotherapeutic agents; one difference between MRP1 and P-gp specificity for substrates is that taxanes are poor substances for $\mathrm{MRP}^{\left[{ }^{[6]}\right]}$. In addition, MRP1 transports many endogenous and exogenous compounds as such or conjugated to GSH, glucuronides, and sulphates ${ }^{[62,63]}$. Other members of the ABCC family were described, which includes $\mathrm{ABCC} 2-6$ and $\mathrm{ABCC} 10-12^{[64]}$. It was recently reported that also overexpression of some of these sister proteins was associated with resistance to anticancer drugs ${ }^{[65]}$.

The last discovered ABC efflux transporter involved in MDR is BCRP/ABCG2/MXR ${ }^{[6]]}$. Its overexpression was first observed in 1998 in the multidrug resistant human breast cancer cell line MCF-7/AdrVp ${ }^{[6]]}$. BCRP belongs to the subfamily $\mathrm{G}$ of the $\mathrm{ABC}$ transporter superfamily ${ }^{[67]}$ and is a $72-\mathrm{kDa}$ half-ABC transporter, consisting of 655 amino acids; it has one TMD with six alpha-helices at the C-terminal end and one NBD at 


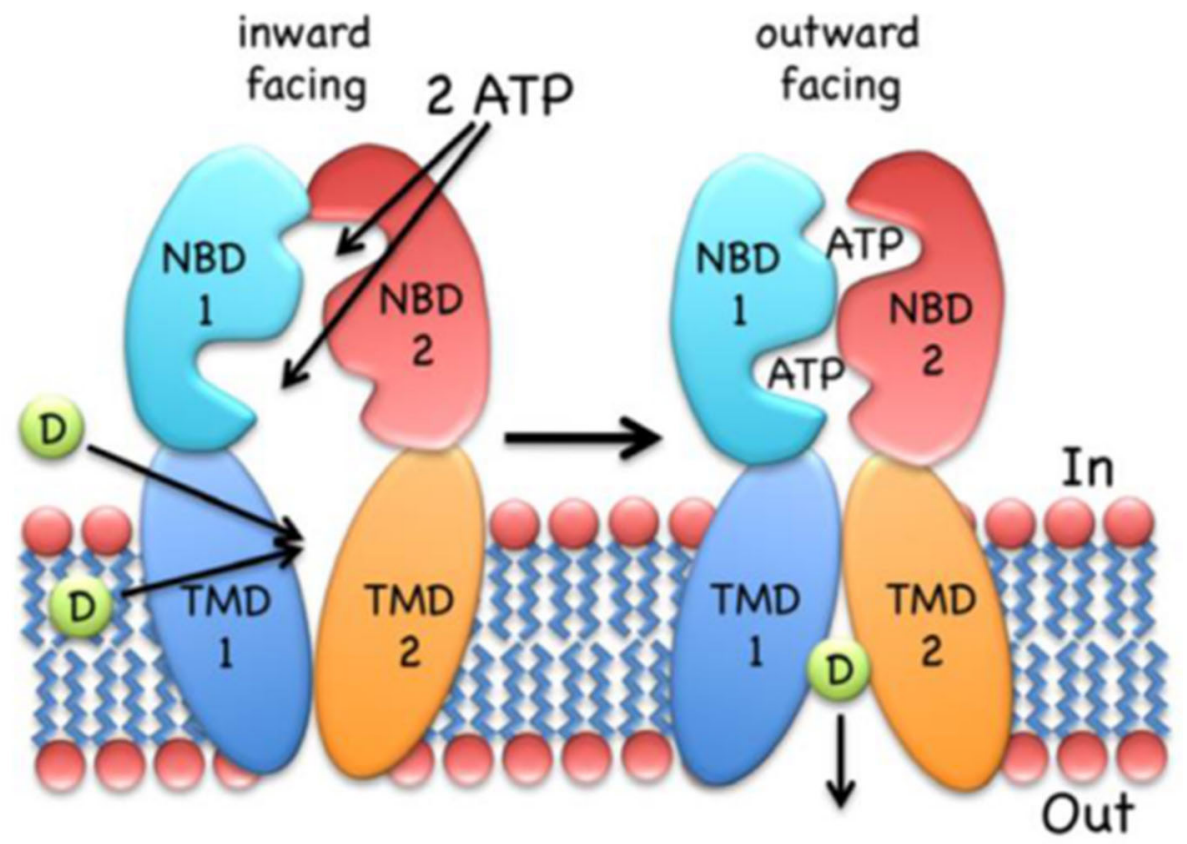

Figure 2. The inward-facing exporter binds substrate ( $D$, drug) from the cytoplasm or the inner leaflet of the bilayer. After binding two molecules of MgATP, the nucleotide-binding domains (NBDs) dimerize and switch the transmembrane domain (TMDs) from the inwardto the outward-facing conformation, followed by the release of the drug to the extracellular environment. ATP hydrolysis, ADP/Pi release and NBD dissociation reset the transporter to the inward-facing conformation. The figure is quoted with permission from Wilkens ${ }^{[47]}$.

the N-terminal end. Nevertheless, it has been shown that the half-transporter BCRP, through the formation of disulfide bonds, functions as homodimer or homooligomer ${ }^{[68-70]}$. More recent investigations suggested that the transporter operates as a homotetramer ${ }^{[71]}$. BCRP is physiologically expressed in the gastrointestinal tract, liver, kidney, brain, endothelium, mammary tissue, testis and placenta; moreover, overexpression of this transporter was reported in untreated solid tumors and in different types of leukemia ${ }^{[72]}$, where the pump exhibits a very broad specificity for substrates like P-gp and MRP1. In fact BCRP actively extrudes a broad range of endogenous and exogenous substrates across biological membranes, as sulfate conjugates, glutamated folates, porphyrins ${ }^{[56]}$, and anticancer drugs like imatinib, methotrexate, camptothecin derivatives and epipodophyllotoxins ${ }^{[73]}$.

The relationships between $\mathrm{ABC}$ efflux transporter expression and tumor drug responses or patient survival have been well established for many years, considering patients after exposure to a chemotherapeutic agent. First evidences were described evaluating P-gp and/or MRP1 expression ${ }^{[17,74,75]}$. Also BCRP expression was observed in many tumors, and some studies indicate that BCRP could be a predictor of survival in patients with leukemia or cancer ${ }^{[76,7]]}$. Interestingly, BCRP was found to be significantly co-expressed with P-gp ${ }^{[78]}$.

On these bases, identification of inhibitors against ABC transporters, such as P-glycoprotein (P-gp/MDR1/ $\mathrm{ABCB} 1$, or multidrug resistance-associated proteins (MRPs/ABCCs), and breast cancer protein (BCRP/ ABCG2) has emerged as critical goal because their inhibition may improve both chemotherapeutic response and patient outcomes. In fact, since the discovery and the clarification of the mechanism of action of the first efflux pump, modulation of the functions of P-gp and sister proteins has been considered an approach for fighting this kind of MDR. MDR reversers, also defined chemosensitizers, are pump modulators that coadministered with antineoplastic agents, which are substrates of the transporters, could restore the efficacy of anticancer drugs in resistant cancer cells ${ }^{[79,80]}$. Therefore drugs possessing modulating properties have been and are actively being sought ${ }^{[81,80]}$. 
Verapamil was the first compound described to be able to reverse drug resistance in leukemia cells ${ }^{[82]}$ exhibiting P-gp modulating activity. Verapamil and other well-known molecules (e.g., quinine, trifluoperazine, progesterone and cyclosporine A) constitute the first generation of P-gp modulators, which were combined with different anticancer drugs. Unfortunately, the first-generation inhibitors were biological active compounds and they were not specifically developed for the modulation of ABC transporters. Moreover, many of them were also substrates for P-gp; thus, the use of high doses of chemosensitizers needed to inhibit the activity of $\mathrm{ABC}$ transporter produced toxic side effects and showed only limited or no benefits ${ }^{[83]}$. However, in the last decades many P-gp modulators have been identified ${ }^{[84,85]}$ and classified in different generations of compounds.

The second generation of P-gp-dependent MDR inhibitors were specifically designed to reduce possible toxicities and obtain higher potency and specificity by modifying the structures of P-gp modulators belonging to the first generation. In this way R-verapamil ${ }^{[86]}$, VX-710 (biricodar) ${ }^{[87]}$ and PSC-833 (valspodar ${ }^{[88]}$ were obtained. Indeed, these derivatives inhibit the function of P-gp, and do not exhibit the original activity of their precursors. Unfortunately, co-administration of the MDR modulators with anticancer drugs elicited pharmacokinetic interactions and altered the absorption, distribution, metabolism and excretion (ADME) of anticancer drugs leading in general to increased toxicity ${ }^{[89,90]}$.

The third generation P-gp dependent MDR modulators such as laniquidar (R101933) ${ }^{[91]}$, ONT-093 (OC14093 ${ }^{[92]}$, zosuquidar (LY335979) ${ }^{[93]}$, elacridar $\left(\mathrm{GF} 120918\right.$ or GW120918) ${ }^{[94]}$ and tariquidar (XR9576) ${ }^{[95]}$ have a high affinity to $\mathrm{ABC}$ transporters at nanomolar concentrations and show a limited CYP3A inhibition ${ }^{[96,97]}$; therefore they exhibit almost no pharmacokinetic interactions with the combined chemotherapeutic drugs, and some of them have reached pre-clinical or clinical stages ${ }^{[98,99]}$. Unfortunately, although in vitro studies have confirmed their effect as MDR modulators, clinical trials suggested that the activities of anticancer drugs were not improved by co-administration of these compounds ${ }^{[100,101]}$, and none of them has been approved for therapy. Nevertheless, the concept that modulation of ABC efflux transporters may overcome MDR is still strong, and the search for new chemosensitizers is still ongoing. More recently, some evidences have demonstrated a MDR reversing activity by using natural products as flavonoids, curcuminoids, taccalonolides and terpenes; so there is a growing interest in exploring the use of natural components of foods/plants as P-gp modulators ${ }^{[99]}$. These natural derivatives, together with some surfactant as Cremaphor EL and Nonidet P40 are considered as the fourth generation of MDR reversal agents ${ }^{[102]}$.

In the meantime, an intriguing aspect that emerged from the studies was that the $\mathrm{ABC}$ transporters $\mathrm{P}$-gp, MRPs and BCRP are often co-expressed in tumors and that they have an overlapped specificity for a variety of substrates ${ }^{[103]}$. Therefore, selective inhibition of one efflux transporter could be compensated by the remaining transporters, and in the last years many studies were devoted to evaluating the inhibitory activity of new derivatives on cells overexpressing different transporters.

In the last two decades, after the discovery of BCRP, many new molecules acting as BCRP-dependent MDR modulators were reported, but also in this field sound SARs are lacking. BCRP is overexpressed in several haematological and solid tumours together with P-gp ${ }^{[78]}$. Moreover, P-gp and BCRP are the two main ABC transporters placed at the $\mathrm{BBB}$ and reduce the ability to cross the $\mathrm{BBB}$ of many drugs that are substrates of these two proteins including chemotherapeutic agents.

On this basis, selective BCRP inhibitors and dual P-gp/BCRP ones are needed to define sound structureactivity relationships (SARs) and to discover new leads for the development of new molecules. In this paper, both selective BCRP inhibitors and dual P-gp/BCRP inhibitors reported in the literature in the last five years were analysed and reviewed. Chemical structures, SARs and reported pharmacological characterization were described. 
<smiles>COc1cc(O)c2c(=O)c(OC)c(-c3ccc(OC)c(OC)c3)oc2c1</smiles><smiles>COc1cc(OC)c2c(=O)c(OC)c(-c3ccc(OC)c(OC)c3)oc2c1</smiles><smiles>COc1ccc2[nH]cc(CCNC(=O)c3cc(=O)c4c(OCc5ccc(Br)cc5)cccc4o3)c2c1</smiles><smiles>COc1ccc2[nH]cc(CCNC(=O)c3cc(=O)c4c(OCc5ccccc5Br)cccc4o3)c2c1</smiles>

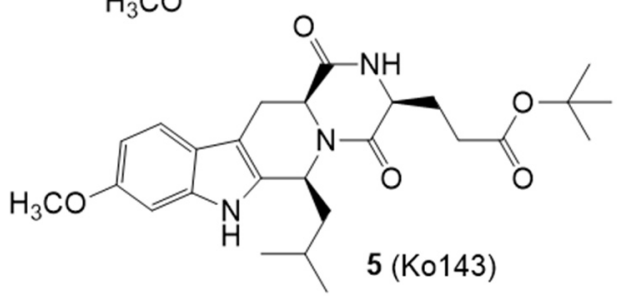

Figure 3. Flavonoids and chromone derivatives

\section{FLAVONOIDS AND CHROMONE DERIVATIVES}

Flavonoids are a group of naturally occurring polyphenolic compounds present in vegetables and fruits. These natural compounds are important constituents of human diet and are well known for their beneficial effects on health. A variety of biological activities have been attributed to flavonoids, these include antioxidant, anti-inflammatory, anti-mutagenic, anti-viral, and anti-allergic properties and these compounds may exert protective effects against various disease conditions including cardiovascular disease and cancer $^{[104]}$. In the last decades a variety of flavonoids have been investigated for their capacity to modulate the P-gp and BCRP activity. Some polyphenols can overcome cancer chemotherapeutic resistance as multidrug reversal agents and the combination of flavonoids and chemotherapy seems to be an interesting approach for cancer treatment ${ }^{[105-107]}$. Recently, several naturally occurring flavonoids as well as few synthetic analogues have been reported to be good inhibitors of $\mathrm{BCRP}^{[108-114]}$.

Chromones are a class of natural compounds, characterized by the presence of 1,4-benzopyrane structure. Some functionalized chromones were described as highly active compounds as MDR modulators ${ }^{[115]}$.

Flavones bearing a methoxy group at position 3 of the pyranone ring [Figure 3] were recently identified as effective and selective BCRP inhibitors as they were able to increase the accumulation of Hoechst 33342 and pheophorbide A in MDCK BCRP cells ${ }^{[116]}$. Among these compounds, 1 was identified as a potent and selective BCRP inhibitor, while pentamethyl quercetin (2) was identified as a broad-spectrum inhibitor that showed substantial effect also on both P-gp and MRP1, evaluated by calcein AM assay on P-gp-overexpressing A2780 adr cells and MRP1-overexpressing $2008 \mathrm{MRP} 1$ cells, respectively. Studies to investigate the substrate or inhibitor nature of compound 1 revealed that this 3-methoxy flavone was able to stimulate ATPase activity at low concentrations suggesting that it binds to the high affinity activating site of the transporter ${ }^{[17]}$. Otherwise, at higher concentrations it was able to lower the ATPase activity, suggesting that the affinities for the activating and inhibitory site are relatively close to each other. 


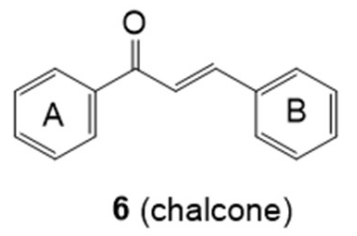<smiles>COc1cccc(OC)c1/C=C/C(=O)c1ccc(C(=O)/C=C/c2c(OC)cccc2OC)cc1</smiles><smiles>O=C(/C=C/c1ccc2c(c1)CCCC2)c1ccccc1</smiles>

A<smiles>Oc1ccc2nccnc2c1</smiles>

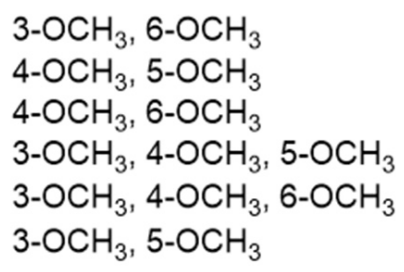
8: $I C_{50}=1.7 \mu \mathrm{M}$
9: $I C_{50}=1.9 \mu \mathrm{M}$
10: $I \mathrm{C}_{50}=1.4 \mu \mathrm{M}$
11: $\mathrm{IC}_{50}=2.2 \mu \mathrm{M}$
12: $I C_{50}=1.4 \mu \mathrm{M}$
13: $\mathrm{IC}_{50}=2.1 \mu \mathrm{M}$

B<smiles>COc1ccc2ccccc2c1</smiles><smiles>[Al]c1ccc2c(c1)OCO2</smiles>

14: $I C_{50}=17.0 \mu \mathrm{M} \quad 19: I C_{50}=5.6 \mu \mathrm{M}$

15: $\mathrm{IC}_{50}=4.1 \mu \mathrm{M}$

20: $\mathrm{IC}_{50}=3.5 \mu \mathrm{M}$

16: $I C_{50}=11.2 \mu \mathrm{M}$

17: $\mathrm{IC}_{50}=2.5 \mu \mathrm{M}$

18: $\mathrm{IC}_{50}=23.3 \mu \mathrm{M}$
21: $I C_{50}=6.1 \mu \mathrm{M}$

22: $I C_{50}=0.94 \mu \mathrm{M}$<smiles>COc1ccc(/C=C/C(=O)c2ccc3ccccc3c2)c(OC)c1OC</smiles>

23<smiles>COc1cccc(OC)c1/C=C/C(=O)c1ccc2c(c1)OCO2</smiles>

Figure 4. Chalcone derivatives

The chromone derivative 3 (MBL-II-141) ${ }^{[118,119]}$ [Figure 3] is a potent and selective BCRP inhibitor endowed with excellent in vivo activity and very low toxicity. In 2016, a series of derivatives of compound 3 were synthesized and studied for their ability to inhibit the efflux of mitoxantrone (an anticancer drug and substrate of BCRP) in BCRP-transfected HEK293 cells and for their cytotoxicity ${ }^{[120]}$. Among the investigated compounds, derivative 4, bearing a 2-bromine atom on the benzyloxy moiety, was 3 -fold more potent than 3 $\left(\mathrm{EC}_{50}=0.086 \mathrm{M}\right.$ versus $\left.0.26 \mathrm{M}\right)$. It showed the same potency as $\operatorname{Ko143}(5)^{[121,122]}(0.074 \mathrm{M})$, the most potent and selective BCRP inhibitor known today, but with the advantage of a lower intrinsic cytotoxicity.

\section{CHALCONE DERIVATIVES}

Derivatives of chalcone (6) [Figure 4] are a class of natural compounds, precursor of flavonoids, characterized by the presence of two phenyl moieties, A-ring and B-ring. They were shown to possess a variety of biological activities and several research groups have investigated chalcone derivatives for their P-gp and BCRP inhibitory effect ${ }^{[123-126]}$.

Differently substituted bis-chalcones have been investigated for their ability to inhibit mitoxantrone efflux from BCRP-transfected HEK293 cells ${ }^{[127]}$. The number and position of methoxy groups were critical for activity since compounds without this group had low efficiency; the best derivative was compound $7\left(\mathrm{EC}_{50}\right.$ $=0.2 \mu \mathrm{M}$ ) with methoxy groups in position 2,6 of rings B of the two chalcone moieties. This compound, at the not cytotoxic $0.1 \mu \mathrm{M}$ concentration, was able to sensitize to mitoxantrone toxicity the BCRP -transfected cells, as monitored by MTT assays, decreasing the $\mathrm{IC}_{50}$ (cytotoxic concentration for $50 \%$ cell survival) of 
mitoxantrone from $26.6 \mathrm{nM}$ to $7.2 \mathrm{nM}$. Compound 7 can be considered a BCRP-selective inhibitor since it was not able to inhibit the P-glycoprotein-mediated mitoxantrone efflux in P-gp-transfected NIH-3T3 cells or the MRP1-mediated calcein efflux in MRP1-transfected HEK293 cells. The synergistic inhibitions observed for compound 7 when combined with a low concentration of chromone 3 (MBL-II-141) suggested that the two inhibitors may bind to distinct sites within BCRP. Compound 7 stimulated the BCRP basal ATPase activity while compound 3 was an inhibitor, suggesting different mechanisms of interaction.

A series of chalcones containing a bicyclic B-ring [Figure 4] were synthesized and tested as BCRPmediated mitoxantrone efflux inhibitors on human fibroblast HEK293 cell lines transfected with BCRP $\left(\right.$ HEK293-ABCG2) ${ }^{[128]}$. The quinoxaline derivatives appeared more efficient than the 2-naphthyl or 3,4-methylenedioxyphenyl analogues. In all cases, the activity depends on the number and position of methoxy groups present on the phenyl A-ring and two or three methoxy groups produce a maximal inhibition. Molecular modeling indicated both electrostatic and steric positive contributions of these substituents.

The best quinoxaline derivatives (8-13), displayed $\mathrm{IC}_{50}$ values in the range 1.4-2.2 $\mu \mathrm{M}$ that are lower than those of the 2-naphthyl or 3,4-methylenedioxyphenyl analogues (compounds 14-18 and 19-22, respectively). In the 2-naphthyl or 3,4-methylenedioxyphenyl series, a higher potency was observed when the 2-naphthyl or 3,4-methylenedioxyphenyl group was shifted to the A-ring and methoxy substituents were shifted to the phenyl B-ring (23 and 24) indicating that the chalcones are functionally asymmetric ${ }^{[128]}$.

In 2016, Kraege et al. ${ }^{[129]}$ investigated a series of 22 heterodimeric derivatives characterized by the presence of a quinazoline ring linked to a chalcone scaffold for their ability to inhibit BCRP, using the pheophorbide A assay on the MDCK II BCRP cell line [Figure 5]. The inhibitory activity toward P-gp and MRP1 was evaluated using the calcein accumulation assay on A2780 adr (P-gp) and H69AR (MRP1) cell lines, respectively. Structural features for inhibitory activity against BCRP were identified, like the presence of a quinazoline 2-phenyl ring bearing two methoxy groups and the presence of the 3,4-dimethoxy substituent on chalcone ring $\mathrm{B}$, which caused an increase of inhibitory activity. The most potent BCRP inhibitor of this series was compound $25\left(\mathrm{IC}_{50}=0.19 \mathrm{M}\right)$ showed 25 fold higher inhibitory potency against BCRP than the individual building blocks, 2-(3,4-dimethoxyphenyl)-4-anilinoquinazoline $(26)\left(\mathrm{IC}_{50}=4.09 \mu \mathrm{M}\right)^{[130]}$ and $(E)$ 1,3-bis(3,4-dimethoxyphenyl)prop-2-en-1-one $(27)\left(\mathrm{IC}_{50}=5.12 \mathrm{M}\right)^{[131]}$. Compound 25 was able to reverse MDR for the BCRP substrate SN-38 in the same concentration range and to the same extent as Ko143 (5). Most compounds showed low inhibition of P-gp and no activity against MRP1, but some derivatives displayed a good activity also against P-gp, in some cases even higher than against BCRP. Compound 28, on which the acryloylphenyl residue of the chalcone is shifted in the meta position of ring $\mathrm{A}$, showed $\mathrm{IC}_{50}$ value of $0.48 \mathrm{M}$ on A2780 adr (P-gp) cell line and 0.60 M on MDCK II BCRP cell line; thus it can be considered as a dual P-gp/BCRP inhibitor ${ }^{[129]}$.

Kraege et al. ${ }^{[132]}$, in 2016, reported another study on a series of 35 acryloylphenylcarboxamides obtained combining the chalcone scaffold with different substituted acid chlorides through an amide linker at position 2', 3', or 4' on ring A of the chalcone moiety [Figure 6]. These compounds were investigated for their inhibitory activity on the BCRP overexpressing MDCK II BCRP cell line by using the pheophorbide $\mathrm{A}$ and Hoechst 33342 assays. The inhibitory activity against P-gp and MRP1 was studied on the P-gp overexpressing A2780 adr cells and MRP1 overexpressing H69AR cells, respectively, by using the calcein AM assay. The ortho position of the amide linker and the 3,4-dimethoxy groups on ring B have been found important for inhibitory activity. The most potent compound 29, which contains an unsubstituted thiophene ring, showed $\mathrm{IC}_{50}$ values of $0.60 \mathrm{M}$, in the pheophorbide $\mathrm{A}$ assay, and of $0.50 \mathrm{M}$ in the Hoechst 33342 assay. This compound showed less affinity toward P-gp and was almost inactive against MRP1. Analogously, almost all compounds demonstrated some P-gp inhibition, but none exhibited significant activity against 
<smiles>COc1ccc(/C=C/C(=O)c2ccc(Nc3nc(-c4ccc(OC)c(OC)c4)nc4ccccc34)cc2)cc1OC</smiles><smiles>COc1ccc(-c2nc(Nc3ccccc3)c3ccccc3n2)cc1OC</smiles><smiles>COc1ccc(/C=C/C(=O)c2ccc(OC)c(OC)c2)cc1OC</smiles><smiles>COc1ccc(/C=C/C(=O)c2cccc(Nc3nc(-c4ccc(OC)c(OC)c4)nc4ccccc34)c2)cc1OC</smiles>

Figure 5. Chalcone quinazoline derivatives

MRP1. Compound 30 showed the highest inhibitory potency against P-gp with $\mathrm{IC}_{50}=0.494 \mathrm{M}$ on A2780 adr (P-gp) cell line and also a quite good inhibitory activity against BCRP $\left(\mathrm{IC}_{50}=0.971 \mathrm{M}\right)$. For this reason, this compound can be considered as a dual P-gp/BCRP inhibitor.

In the same year, the same research group, reported another series of acryloylphenylcarboxamides [Figure 6] and of acryloylphenylcarboxylates with a 4'-methoxy group on ring A of the chalcone ${ }^{[133]}$. These compounds were investigated for their inhibitory activity on the BCRP overexpressing MDCK II BCRP cell line by using the pheophorbide A and Hoechst 33342 assays. The inhibitory activity against P-gp and MRP1 was studied by using the calcein AM assay on P-gp overexpressing A2780 adr and MRP1 overexpressing H69AR cells, respectively. The presence of a 4'-methoxy group on ring A of the chalcone moiety leads to an increased inhibitory activity toward BCRP in comparison with the unsubstituted series ${ }^{[132]}$. No inhibitory effect for MRP1 and weak affinity toward P-gp was observed, except for compounds bearing an additional methoxy group at the benzamide. Analyzing the structure-activity relationships, the presence of 3,4-dimethoxy groups on ring $B$ of the chalcone was the most efficient pattern among those investigated on MDCK II BCRP cell line, and the replacement of the amide function with an ester decreased inhibitory effects toward BCRP. Compound 31 was the most potent derivative on $\mathrm{BCRP}$ with $\mathrm{IC}_{50}=0.219 \mathrm{M}$, and it can be considered rather $\mathrm{ABCG} 2$ selective since on P-gp it showed an $\mathrm{IC}_{50}$ value of $1.13 \mathrm{M}$. On the contrary compounds 32 and 33 can

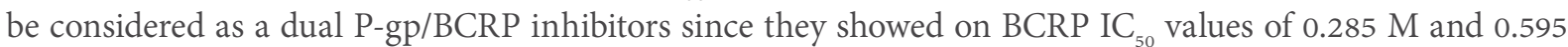
$\mathrm{M}$, respectively, and on $\mathrm{P}-\mathrm{gp} \mathrm{IC}_{50}$ values of $0.848 \mathrm{M}$ and $0.250 \mathrm{M}$, respectively ${ }^{[133]}$.

With the aim to develop selective as well as broad-spectrum inhibition of the transport proteins involved in MDR, Silbermann et al ${ }^{[134]}$ reported in 2019 a study of the inhibitory effect of chalcone and flavone derivatives against P-gp, MRP1 and BCRP [Figure 7]. These compounds are chalcones variously substituted on rings $\mathrm{A}$ and $\mathrm{B}$, and flavones with acetamido linker at position 2. The inhibitory activity of these compounds against P-gp, MRP1 and BCRP, was studied on P-gp overexpressing A2780 adr and MRP overexpressing H69AR cells, by using the calcein AM assay, and on BCRP-overexpressing MDCK II BCRP cells by using the pheophorbide A assay. Two specific inhibitors of P-gp and BCRP were found: compound 34 that inhibited P-gp-mediated calcein AM efflux with an $\mathrm{IC}_{50}$ value of $1.89 \mathrm{M}$, and compound 35 that was the most potent and selective ABCG2 inhibitor with an $\mathrm{IC}_{50}$ value of $1.97 \mathrm{M}$ regarding BCRP-mediated pheophorbide A efflux. Compounds 36 and 37 were instead dual MRP1/BCRP and P-gp/BCRP inhibitors, respectively. The chalcone derivative 36 showed $\mathrm{IC}_{50}$ values of $12.5 \mathrm{M}$ on MRP1 mediated calcein AM efflux 
<smiles>COc1ccc(/C=C/C(=O)c2ccccc2NC(=O)c2cccs2)cc1OC</smiles>

29<smiles>COc1ccc(/C=C/C(=O)c2ccccc2NC(=O)c2cnc3ccccc3c2)cc1OC</smiles><smiles>[R]C(=O)Nc1cc(OC)ccc1C(=O)/C=C/c1ccccc1</smiles>

$\begin{array}{lll}31 & \mathrm{R}_{1}=\text { phenyl } & \mathrm{R}_{2}=3,4-\mathrm{OCH}_{3} \\ 32 & \mathrm{R}_{1}=\text { 2-methoxyphenyl } & \mathrm{R}_{2}=3,4-\mathrm{OCH}_{3}\end{array}$

$33 \mathrm{R}_{1}=2$-methoxyphenyl $\mathrm{R}_{2}=3,5-\mathrm{OCH}_{3}$

Figure 6. Acryloylphenylcarboxamide derivatives<smiles>Cc1ccc(-c2c(OCC(=O)Nc3cccc4ccccc34)oc3ccccc3c2=O)cc1</smiles><smiles>COc1cc(C(=O)/C=C/c2cc(OC)c(OC)c(OC)c2)ccc1O</smiles><smiles>COc1ccc(NC(=O)COc2ccc(C(=O)/C=C/c3cc(OC)c(OC)c(OC)c3)cc2)cc1OC</smiles><smiles>COc1ccc(-c2c(OCC(=O)Nc3cccc4ccccc34)oc3ccccc3c2=O)cc1OC</smiles>

Figure 7. Chalcone and flavone derivatives

and of 3.37 M on BCRP-mediated pheophorbide A efflux. The flavone derivative 37 showed $\mathrm{IC}_{50}$ values of 5.43 M on P-gp mediated calcein AM efflux, and of 3.75 M on BCRP-mediated pheophorbide A efflux ${ }^{[134]}$.

\section{SCHIZANDRIN DERIVATIVES}

Some synthetic derivatives of the natural compound schizandrin extracted from Schisandra chinensis, have the ability to restore drug sensitivity at non-toxic concentrations via direct interaction with P-gp. Bifendate (DDB) (38) [Figure 8] is an analogue of schizandrin $\mathrm{C}^{[135]}$, used for the treatment of chronic viral hepatitis $\mathrm{B}$ in China. Bifendate showed MDR reversal activity in vitro and in vivo, increasing intracellular accumulation of anticancer drugs and promoting cancer cell apoptosis through inhibition of $\mathrm{P}-\mathrm{gp}^{[136]}$.

Bifendate-chalcone hybrids have been described as potent P-glycoprotein inhibitors with little intrinsic cytotoxicity $^{[137]}$ [Figure 8]. On K562/A02 cells overexpressing P-gp (induced by adriamycin), compound 39 was able to increase the accumulation of rhodamine 123 more potently than the classical P-gp inhibitor verapamil (40) showing a very low intrinsic cytotoxicity $\left(\mathrm{IC}_{50}>200 \mathrm{M}\right)$. Furthermore, 39 showed no stimulation of the P-gp ATPase activity, suggesting it was not a P-gp substrate. In a following paper, the reversing activity of compound 39 on BCRP and MRP1 has been investigated on BCRP-transfected stable HEK293/BCRP cells and MRP1-transfected stable HEK293/MRP1 cells, respectively ${ }^{[138]}$. This compound 
<smiles>COC(=O)c1cc(OC)c2c(c1-c1c(C(=O)OC)cc(OC)c3c1OCO3)OCO2</smiles>

38 (Bifendate (DDB))<smiles>COC(=O)c1cc(OC)c2c(c1-c1c(/C=C/C(=O)c3cc(C)ccc3C)cc(OC)c3c1OCO3)OCO2</smiles><smiles>COc1ccc(CCN(C)CCCC(C)(C)C(C)C)cc1OC</smiles>

40 (verapamil)<smiles>[R]C#[R]CCc1ccccc1CCc1ccc2c(c1)OCO2</smiles>

Figure 8. Schizandrin derivatives

exhibited little intrinsic cytotoxicity $\left(\mathrm{IC}_{50}>100 \mathrm{M}\right)$ against HEK293/BCRP cells and their corresponding BCRP-negative HEK293/VEC cells. It could reverse the BCRP-mediated efflux of the mitoxantrone with an activity almost comparable with the BCRP inhibitor Ko143 (5). Little inhibitory effect on multidrug resistance-associated protein 1 (MRP1) was showed in the adriamycin (a MRP1 substrate) accumulation test on MRP1-transfected stable HEK293/MRP1 cells. Thus compound 39 can be considered as a dual P-gp/ BCRP inhibitor.

Gu et al. ${ }^{[139]}$ reported that a series of bifendate derivatives bearing dibenzo[c,e]azepine scaffold could reverse P-gp-mediated MDR by blocking drug efflux function in K562/A02 MDR cells [Figure 8]. The most potent compounds 41 and 42 reversed P-gp-mediated multidrug resistance (MDR) with an activity higher than bifendate (38) and verapamil (40). Compound 42 showed no stimulation on the P-gp ATPase activity, suggesting it is not a substrate of P-gp.

Moreover compounds 41 and 42 could markedly increase mitoxantrone accumulation in HEK293/BCRP cells via inhibiting BCRP efflux function with an inhibitory activity comparable to that of the classical BCRP inhibitor Ko143 $5^{[140]}$. Compound 42 could not increase the MRP1 substrate adriamycin accumulation in MRP1-mediated MDR in MRP1-transfected stable HEK293 cells (HEK293/MRP1 cells), suggesting 42 may be considered a dual inhibitor of P-gp/BCRP. 
<smiles>COCOc1cc(/C=C/C(=O)/C=C/c2cc(OCOC)cc(OCOC)c2)cc(OCOC)c1</smiles><smiles>COc1cc(/C=C/C(=O)/C=C/c2cc(OC)c(OC)c(OC)c2)cc(OC)c1O</smiles>

Figure 9. Curcumin derivatives

\section{CURCUMIN DERIVATIVES}

Curcumin is a polyphenolic natural product known for its properties as antioxidant, ant-inflammatory and antitumor agent. Its metabolites or constituents were found able to reverse the drug resistance in cells mediated by P-gp, MRP1 and BCRP, in particular ${ }^{[141-143]}$.

In 2017, Murakami et al. ${ }^{[14]}$ investigated a series of 24 synthetic curcumin analogues on the transport function of BCRP by using BCRP-overexpressing K562/BCRP cells [Figure 9]. Two curcumin analogues $(43,44)$ were able to inhibit significantly the efflux of the BCRP substrates mitoxantrone and pheophorbide A from BCRP-overexpressing K562/BCRP cells. These compounds stimulated the ATPase activity of BCRP at nanomolar concentrations and inhibited the photolabeling of BCRP with iodoarylazidoprazosin, suggesting that they are able to inhibit the function of BCRP by directly interacting at the substrate-binding site.

\section{QUINAZOLINE DERIVATIVES}

Recently, it was demonstrated that some tyrosine kinase inhibitors (TKIs) are able to inhibit P-gp or BCRP transporters. The quinazoline based TKI gefitinib (45) [Figure 10], in particular, has been reported to be a potent BCRP inhibitor ${ }^{[145]}$.

In 2016, Krapf et al. ${ }^{[146]}$ investigated several meta and para substituted 4-anilinoquinazolines for their inhibitory activity on BCRP using the Hoechst 33342 accumulation assay on the BCRP overexpressing MDCK II BCRP cell line [Figure 10]. The inhibitory activity on P-gp and MRP1 was investigated on the P-gp overexpressing cell line A2780 adr and the MRP1 overexpressing cell line H69AR respectively, by using the calcein AM accumulation assay. The compounds that showed the best inhibitory activity toward BCRP were characterized by the presence of hydroxy, cyano, nitro, acetamido, and fluoro groups at the 4-aniline scaffold. In the Hoechst 33342 accumulation assay toward the BCRP overexpressing MDCK II cell line, compounds 46 and 47 were the most potent inhibitors with a 3-fold higher potency than Ko143 (5) ( $\mathrm{IC}_{50}$ $=69.9,80.0$ and $221 \mathrm{nM}$, respectively). These compounds showed no inhibitory activity toward P-gp and MRP1 thus proving to be highly BCRP selective. Compounds 48 and 49 that showed on BCRP IC ${ }_{50}$ values of 0.152 and $1.150 \mathrm{M}$ respectively, exhibited also some inhibitory activity toward P-gp $\left(\mathrm{IC}_{50}=1.86\right.$ and $3.00 \mathrm{M}$, respectively) but no activity toward MRP1. Therefore, they can be considered dual P-gp/BCRP inhibitors.

Some quinoline analogues were also studied to evaluate the importance of the nitrogen atom at position 3 and the results showed that the presence of a nitrogen in this position is crucial for activity and selectivity toward $\mathrm{BCRP}^{[146]}$ [Figure 10]. In fact, as example, compound 50 showed a low inhibitory activity towards $\mathrm{BCRP}\left(\mathrm{IC}_{50}=1.63 \mathrm{M}\right)$, a quite good activity on P-gp $\left(\mathrm{IC}_{50}=0.66 \mathrm{M}\right)$ and was able also to slightly inhibit the calcein AM efflux on the MRP1 overexpressing cell line H69AR $\left(\mathrm{IC}_{50}=5.80 \mathrm{M}\right)$.

The next year, Krapf et al. ${ }^{[147]}$ reported another series of BCRP modulators based on quinazoline scaffold [Figure 10]. These compounds are 2-phenyl-4-anilinoquinazolines with various substituents on the aromatic systems at position 2 and 4 of the quinazoline scaffold. The Hoechst 33342 accumulation assay was used to investigate their inhibitory activity on BCRP overexpressing MDCK II cell line; the activity on P-gp 


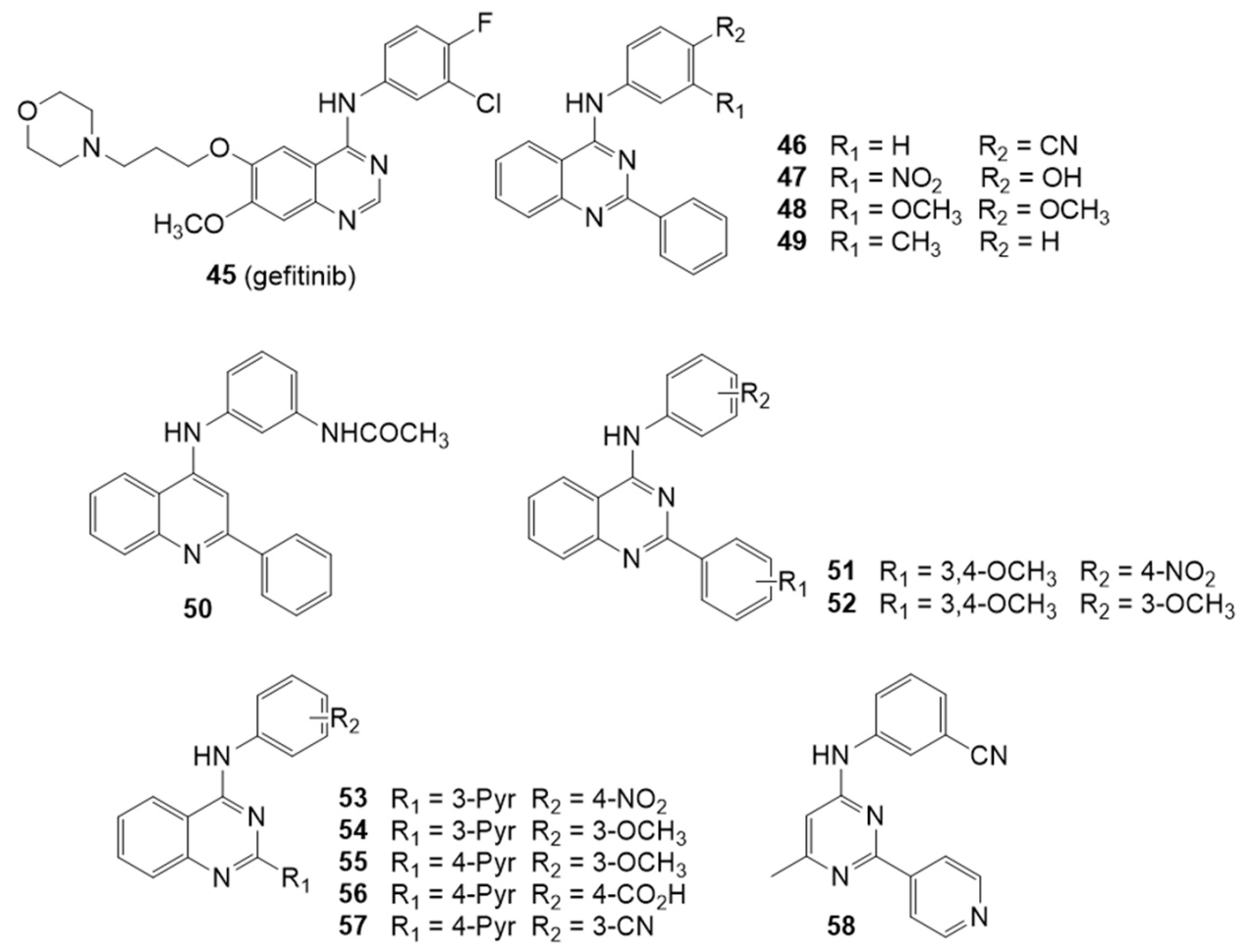

Figure 10. Quinazoline and quinoline derivatives

overexpressing A2780 adr cell line and MRP1 overexpressing H69AR cell line was studied using the calcein AM accumulation assay. This study allowed to identify several potent inhibitors possessing high selectivity toward BCRP as well as some potent dual inhibitors of P-gp/BCRP. On the contrary, only a few compounds showed a slight MRP1 inhibitory activity. The best features for high inhibitory activity on BCRP were the combinations of nitro with methoxy groups. In particular, compounds with 3,4-dimethoxy moieties and meta or para nitro substituents on the two aromatic systems, were found to be highly potent. The most potent compound was 51 that showed an $\mathrm{IC}_{50}$ value of $44.2 \mathrm{nM}$, that is five time lower than that of Ko143 (5) $\left(\mathrm{IC}_{50}=221 \mathrm{nM}\right)$. Several compounds with two or more methoxy groups showed inhibitory activity toward P-gp. Compound 52, in the calcein AM accumulation assay on P-gp overexpressing A2780 adr cell line, was more potent than the standard reference cyclosporine $\mathrm{A}\left(\mathrm{IC}_{50}=1.04\right.$ and $1.21 \mathrm{M}$, respectively); it displayed an $\mathrm{IC}_{50}$ value of $0.365 \mathrm{M}$ on BCRP while was inactive on MRP1. Compounds 51 and 52 were further studied to define their mode of interaction with the BCRP substrate Hoechst 33342 which acts as fluorescent dye. A competitive binding mode was found for compound 51, while compound 52 was found to be a noncompetitive inhibitor.

In the same year a series of 4-anilino-2-pyridylquinazolines containing also compounds with the quinazoline scaffold reduced to a 4-methylpyrimidine was reported ${ }^{[148]}$ [Figure 10]. The inhibitory activity towards BCRP was evaluated by the Hoechst 33342 accumulation assay using the MDCK II BCRP cell line. The activity on P-gp and MRP1 was investigated by the calcein AM assay using P-gp overexpressing cell line A2780 adr and MRP1 overexpressing cell line H69AR, respectively.

The most potent 3-pyridyl derivative 53 contained a para nitro-phenyl moiety and showed in the Hoechst 33342 accumulation assay an $\mathrm{IC}_{50}$ value of $64.1 \mathrm{nM}$, which is 3.5 -fold lower than for the reference compound Ko143 (5) $\left(\mathrm{IC}_{50}=227 \mathrm{nM}\right)$. None compounds showed significant activity toward MRP1 while compounds with one or more methoxy groups at the phenyl ring showed activity toward P-gp as compounds $54\left(\mathrm{IC}_{50}=\right.$ 
<smiles>COc1cc2c(cc1OC)CN(CCc1ccc(NC(=O)c3cc(OC)c(OC)cc3NC(=O)c3cnc4ccccc4c3)cc1)CC2</smiles><smiles>CCCc1ccc(NC(=O)c2ccccc2NC(=O)c2ccc([N+](=O)[O-])cc2)cc1</smiles><smiles>Cc1ccc(C(=O)Nc2ccccc2C(=O)Nc2ccc(C(=O)c3ccccc3)cc2)cc1</smiles>

Figure 11. Tariquidar derivatives

$4.78 \mathrm{M})$ and $55\left(\mathrm{IC}_{50}=5.43 \mathrm{M}\right)$. Interestingly, compound 56 with a 4-carboxy group at phenyl moiety showed the best $\mathrm{P}$-gp inhibitory activity $\left(\mathrm{IC}_{50}=3.67 \mathrm{M}\right)$. Among the 4-methylpyrimidine derivatives, exemplified by 58, several compounds yielded good BCRP activity but none showed significant activity toward P-gp. In the Hoechst 33342 accumulation assay the 4-methylpyrimidine derivative 58 showed an inhibitory activity similar to the corresponding quinazoline analogue $57\left(\mathrm{IC}_{50}=132\right.$ and $134 \mathrm{nM}$, respectively) demonstrating the high ligand efficacy of this scaffold ${ }^{[148]}$.

\section{TARIQUIDAR DERIVATIVES}

Tariquidar (XR9576) (59) [Figure 11] is a third generation P-gp inhibitor that produces specific and effective inhibition of P-gp function at nanomolar concentrations ${ }^{[149-150]}$ and reached phase III clinical trials. However, no substantial benefits have been established due to inefficacy and toxic effects ${ }^{[151]}$. Tariquidar (59) showed dual inhibitory activity on P-gp than BCRP, being two times more selective in inhibiting P-gp than $\mathrm{BCRP}^{[152]}$, and it has been considered a good lead compound in the search for new MDR inhibitors ${ }^{[153]}$.

The deletion of the tetrahydroisoquinoline group of tariquidar (59) led to compounds that were shown to be selective BCRP inhibitors ${ }^{[152-154]}$ [Figure 11]. In 2015, Marighetti et al ${ }^{[155]}$ reported a quantitative structureactivity relationship (QSAR) study of this class of BCRP inhibitors. The inhibitory activities against BCRP and P-gp were determined on BCRP-overexpressing MCF-7 MX cells, by a Hoechst 33342 assay, and on A2780 adr cells by a calcein AM assay, respectively.

By the comparison between activity and calculated $\log \mathrm{P}$ values a tendency of higher activity with greater lipophilicity was observed. In fact, the most BCRP active compounds 60 and 61 are the most lipophilic. Compound 60 showed high and selective activity for BCRP $\left(\mathrm{IC}_{50}=0.94 \mathrm{M}\right)$ since no P-gp inhibitory activity was observed. Otherwise, compound 61 was active also on P-gp despite with lower potency $\left(\mathrm{IC}_{50}=0.56 \mathrm{M}\right.$ on BCRP and 6.07 M on P-gp ${ }^{[155]}$.

Compound 62 (HM30181) has been recently identified as a third-generation P-gp inhibitor ${ }^{[156]}$ [Figure 12]. This compound is a tetrazole derivative structurally related to tariquidar (59) with a tetrazole ring instead of an amide linker. 
<smiles>COc1cc2c(cc1OC)CN(CCc1ccc(-n3nnc(-c4cc(OC)c(OC)cc4NC(=O)c4cc(=O)c5ccccc5o4)n3)cc1)CC2</smiles>

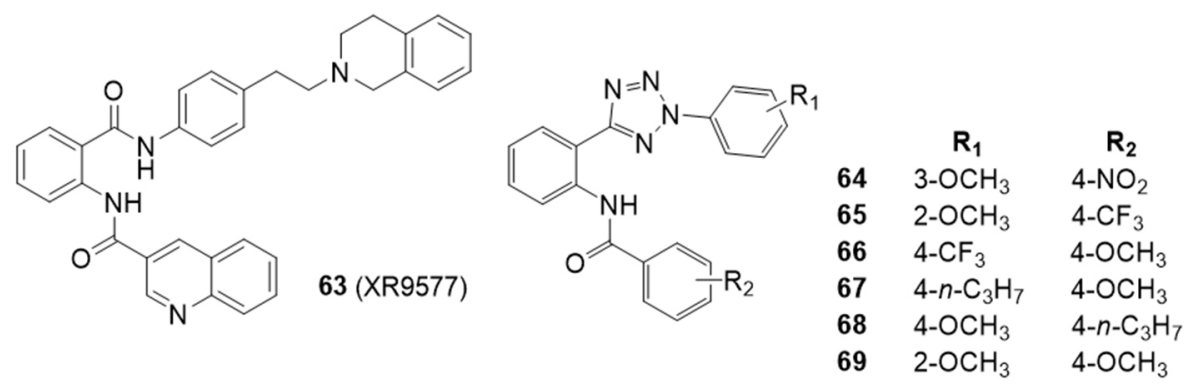

Figure 12. HM30181 derivatives

In 2015, Köhler et al. ${ }^{[157]}$ reported 21 tariquidar derivatives lacking the tetrahydroisoquinoline moiety and, as compound 62, an amide linker was replaced by a tetrazole ring [Figure 12]. The inhibitory activity against BCRP was evaluated by the Hoechst 33342 accumulation assay using the MDCK II BCRP cell line. The activity on P-gp and MRP1 was investigated using P-gp overexpressing cell line A2780 adr and MRP1 overexpressing cell line H69AR, respectively, by the calcein AM assay. These compounds lack methoxy groups at their middle phenyl ring as the reference compound XR9577 (63). In general, electron withdrawing groups on the benzamide moiety $\left(\mathrm{R}_{2}\right)$ led to inactive compounds or BCRP inhibitors showing a decreased maximal response [Imax: maximum response of tested compounds in relation to elacridar (63)]; as an example, compound $64\left(\mathrm{R}_{2}=4-\mathrm{NO}_{2}\right)$ was found to be a potent BCRP inhibitor with an $\mathrm{IC}_{50}$ value of 0.0789 $\mu \mathrm{M}$ but showed an Imax value of 58. However, compound $65\left(\mathrm{R}_{2}=4-\mathrm{CF}_{3}\right)$ with an $\mathrm{IC}_{50}$ value of $0.451 \mathrm{M}$ showed a maximal response comparable to that of elacridar (63) and Ko143 (5) $(\operatorname{Imax}=100)^{[157]}$.

The most potent and selective compounds 66, 67 and 68 bearing electron donating groups on the benzamide ring $\left(\mathrm{R}_{2}\right)$ showed about 2-fold higher BCRP inhibitory activities than Ko143 (5) ( $\mathrm{IC}_{50}$ value of $0.0642 \mu \mathrm{M}$, $0.0794 \mu \mathrm{M}, 0.0730 \mu \mathrm{M}$ and $0.128 \mu \mathrm{M}$, respectively).

Compounds 65 and 69 interact with both BCRP and P-gp in fact, a 2-methoxygroup on phenyl tetrazole moiety $\left(\mathrm{R}_{1}\right)$ leads to a moderate inhibitory activity on P-gp lowering BCRP selectivity $\left(65, \mathrm{IC}_{50}=11.0 \mu \mathrm{M}\right.$ on P-gp, $\mathrm{IC}_{50}=0.451 \mu \mathrm{M}$ on BCRP; 69, $\mathrm{IC}_{50}=7.73 \mu \mathrm{M}$ on P-gp, $\mathrm{IC}_{50}=0.180 \mu \mathrm{M}$ on BCRP) ${ }^{[157]}$.

In 2016, Köhler et al. ${ }^{[158]}$ studied another series of phenyltetrazolylphenylamides on BCRP to determine the specific influence of different substituents at the two external phenyl rings (A and C) [Figure 13]. BCRPoverexpressing MDCK II BCRP cell line was used to evaluate the inhibitory effect on BCRP by the Hoechst 33342 or pheophorbide A accumulation assay.

The activity on P-gp and MRP1 was investigated by the calcein AM assay using P-gp overexpressing cell line A2780 adr and MRP1 overexpressing cell line H69AR, respectively. 
The most potent compound on BCRP was the unsubstituted derivative 70 with $\mathrm{IC}_{50}$ values three to four times lower than Ko143 (5) in the Hoechst 33342 accumulation assay or the pheophorbide A accumulation assay, respectively [70, $\mathrm{IC}_{50}=0.0669$ and $0.0640 \mu \mathrm{M}, \mathrm{Ko143}(5), \mathrm{IC}_{50}=0.221$ and $0.276 \mu \mathrm{M}$ ]. A few compounds showed moderate activities on P-gp but, interestingly, compound 71 showed a threefold higher inhibitory activity toward P-gp $\left(\mathrm{IC}_{50}=0.434 \mu \mathrm{M}\right)$ than cyclosporine A $\left(\mathrm{IC}_{50}=1.21 \mathrm{M}\right)$. The good P-gp activity of this hydroxyl derivative is rather surprising since usually hydroxyl substituted compounds are poorer P-gp inhibitors than their methoxy counterparts, due to reduced lipophilicity. Compound 71 is a good dual inhibitor against P-gp and BCRP achieving a BCRP- inhibiting potency like Ko143 5 in the Hoechst 33342 accumulation assay [71, $\left.\mathrm{IC}_{50}=0.204, \mathrm{Ko143}(5), \mathrm{IC}_{50}=0.221\right]$. An investigation on the type of interaction with the BCRP substrates Hoechst 33342 and pheophorbide A of compound 72 and Ko143 (5) revealed that both compounds showed a competitive interaction with the substrate Hoechst 33342 . On the contrary they acted as non-competitive modulators in presence of pheophorbide A; this result suggests that these two compounds bind to a different site of the BCRP protein with respect to pheophorbide $\mathrm{A}$.

Two years later Köhler et al. ${ }^{[159]}$ continued the study on structure-activity relationships of phenyltetrazolylphenylamides derived from tariquidar for BCRP inhibition. Using the unsubstituted $\mathrm{N}-(2-$ (2-phenyl-2H-tetrazol-5-yl)phenyl)-benzamide $70^{[158]}$ as lead structure, 38 new derivatives with several modifications of the three phenyl rings $(\mathrm{A}, \mathrm{B}, \mathrm{C})$ have been synthesized. The 2,5-disubsituted tetrazole moiety was exchanged for bioisosteric structures like 2,5-disubstituted 1,3,4-oxadiazole and an 1,4-disubstituted 1,2,3-1 $H$-triazole. The ortho amide linker was modified and meta and para positioned linkers (inverted amide, sulfonamide, tetrazole) were inserted or the amide linker was removed. Moreover, either ring A and $\mathrm{C}$ were modified.

The study of these compounds on the MDCK II BCRP cell line, using the Hoechst 33342 accumulation assay, revealed that for BCRP a bioisosteric substitution of the tetrazole moiety is not beneficial as well as the modification of the amide in ortho-position. The ring A is essential for BCRP activity since its elimination resulted in inactivity. The introduction of a methoxy group at phenyl ring B exerted a slightly positive effect on the activity since compound 74 showed a similar activity than the corresponding analogue without that substituent (75), previously reported $\left(\mathrm{IC}_{50}=0.0774 \text { and } 0.106 \mathrm{M} \text {, respectively }\right)^{[157]}$.

The modification of the phenyl A in a pyridyl moiety along with the presence of methoxy groups in paraposition of both rings $\mathrm{A}$ and $\mathrm{C}$ improved inhibitory potency; in fact, compound 76, the most potent of the series, showed an $\mathrm{IC}_{50}$ value of $0.0616 \mathrm{M}$ while the corresponding analogue with a phenyl ring in $\mathrm{A}$ (73) showed an $\mathrm{IC}_{50}$ value of $0.199 \mathrm{M}^{[158]}$. Most of the compounds exhibited low activities against P-gp in the calcein AM assays using P-gp overexpressing A2780 adr cell lines which therefore appeared to be selective inhibitors.

Compounds $60^{[155]}$ and $64^{[157]}$ have been used as leads by Gujarati et al. ${ }^{[160]}$ to synthesize several benzamide and phenyltetrazole derivatives with amide and urea linkers between rings B and C [Figure 13]. Various substituents were introduced on rings $A$ and $C$ to explore the consequences of steric, electronic and solubility characteristics on BCRP activity. Several compounds exhibited reversal effects comparable to the known BCRP inhibitor fumitremorgin C (FTC) (77) on the cytotoxicity of mitoxantrone in BCRP-overexpressing H460/MX20 cells at three different concentrations (1, 3, $10 \mathrm{M})$. Fold resistance was calculated as ratio between the $\mathrm{IC}_{50}$ values of the substrate $(\mathrm{MX})$ in presence or absence of inhibitor by the $\mathrm{IC}_{50}$ of parental cells without inhibitors. In the benzamide series the most potent compounds possessing a urea linker were 78 and 79 with fold resistances of 1.51 and 1.62 respectively, at $10 \mathrm{M}$ concentration, proving to be more potent than the lead compound 60 (fold resistance of 2.76). Compounds 80 and 81, with an amide linker, and 82, 83 and 84, with an urea linker, were the most potent analogues in the tetrazole derivatives with fold resistances of $1.39,1.32,1.87,1.76$ and 1.51 respectively, at $10 \mathrm{M}$ concentration; these values were comparable to that of 64 
<smiles>COc1ccc2c3c([nH]c2c1)[C@@H](CC(C)=O)N1C(=O)[C@@H]2CCCN2C(=O)[C@H]1C3</smiles>

77 (fumitremorgin C (FTC))<smiles>[R]c1cccc(NC(=O)Nc2ccccc2C(=O)Nc2cccc([R])c2)c1</smiles>

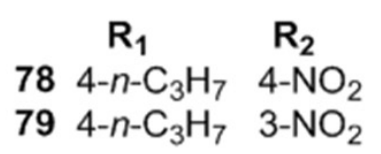<smiles>[R]c1ccc(-n2nnc(-c3ccccc3NC(=O)Oc3ccccc3)n2)cc1</smiles>

\begin{tabular}{llll} 
& $\mathbf{X}$ & \multicolumn{1}{c}{$\mathbf{R}_{\mathbf{1}}$} & \multicolumn{1}{c}{$\mathbf{R}_{\mathbf{2}}$} \\
$\mathbf{8 0}$ & - & $3-\mathrm{OCH}$ & $4-\mathrm{NH}_{2}$ \\
$\mathbf{8 1}$ & - & $3-\mathrm{OCH}_{3}$ & $4-\mathrm{NHCOCH}_{2} \mathrm{Br}$ \\
$\mathbf{8 2}$ & $\mathrm{NH}$ & $3-\mathrm{OCH}_{3}$ & $4-\mathrm{NO}_{2}$ \\
$\mathbf{8 3}$ & $\mathrm{NH}$ & $3-\mathrm{OCH}_{3}$ & $4-\mathrm{NH}_{2}$ \\
$\mathbf{8 4}$ & $\mathrm{NH}$ & $3-\mathrm{OCH}_{3}$ & $4-\mathrm{NHCOCH}_{3}$
\end{tabular}

Figure 13. Tetrazole derivatives

(1.43), the lead compound of the tetrazole analogues with an amide linker. The corresponding value of FTC (77) [Figure 13] is 1.49. These low cytotoxic compounds appeared to be selective BCRP inhibitors since they did not show any reversal effect on paclitaxel resistant P-gp overexpressing SW620/Ad300 cells. Compounds 78, 79, and 80 were found to be stimulators of basal ATPase, while compound 82 was found to be an ATPase inhibitor ${ }^{[160]}$.

A series of amide or sulfonamide derivatives of tariquidar were studied by Li et al.$^{[161]}$ in 2015 [Figure 14]. The compounds were tested for their activity in the inhibition of Rh123 efflux in P-gp transfected cell line (K562/P-gp cells), or of pheophorbide A efflux in BCRP transfected cell lines (K562/BCRP cells). Their cytotoxicity was evaluated in normal human colon fibroblasts (CCD18-Co), human gastric epithelial cell line and primary rat liver cells. These 6,7-dimethoxytetrahydroisoquinoline derivatives were modified on the anthranilic acid amide which was decorated with different functional groups (aromatic, heterocyclic or chain structures). A sulfonamide group was introduced instead of an amide function to improve aqueous solubility and this modification led to specific P-gp inhibitors. In fact, the low toxic and aqueous soluble sulfonamide derivatives 85,86 and 87 , were found to specifically inhibit the Rh123 efflux in P-gp transfected cell lines (K562/P-gp). The amide derivatives 88, 89, 90 and 91 were instead found to dually inhibit P-gp and BCRP-mediated drug efflux in P-gp or BCRP transfected cell lines (K562/P-gp and in K562/BCRP cells, respectively) and their cytotoxicity was much lower than tariquidar (59). The P-gp and BCRP inhibition by these tariquidar derivatives was found to be associated with the inhibition of ATP hydrolysis.

In 2018, Gao et al. ${ }^{[162]}$ investigated 17 derivatives structurally related to tariquidar 59 as P-gp inhibitors [Figure 15]. An amino metil-1,2,3-triazole moiety was inserted instead of the phenylamido group and the second amide of the tariquidar (59) structure was inverted. The effect of these compounds on reversing adriamycin resistance towards P-gp overexpressing cell line (K562/A02) was investigated by MTT method. Structure-activity relationship studies suggested that the presence of a 4-tert-butylphenyl moiety on the inverted amide (compound 92), conferred the best P-gp inhibitory activity $\left(\mathrm{IC}_{50}=1.22 \mathrm{M}\right)$ with a reversal fold $(\mathrm{RF})$ of $39\left[\mathrm{RF}=\right.$ (adriamycin $\mathrm{IC}_{50}$ value without modulator)/(adriamycin $\mathrm{IC}_{50}$ value with 5 $\mathrm{M}$ modulator)], which was close to that of tariquidar $(59)(\mathrm{RF}=49.4)$. On the contrary, the presence of a 3,4-dimethoxyphenethyl group led to a relatively ineffective compound $\left(93, \mathrm{IC}_{50}=41.48 \mathrm{M}\right)$. Compound 92 showed a $24 \mathrm{~h}$ duration lasting, was endowed with low cytotoxic and able to inhibit the efflux of Rh123 in K562/A02. 
<smiles>[R][X]c1cc([R])c([R])cc1C(=O)Nc1ccc(CCN2CCc3cc(OC)c(OC)cc3C2)cc1</smiles>

\begin{tabular}{lllll} 
& $\mathbf{R}_{\mathbf{1}}$ & $\mathbf{R}_{\mathbf{2}}$ & $\mathbf{X}$ & \multicolumn{1}{c}{$\mathbf{R}_{\mathbf{3}}$} \\
$\mathbf{8 5}$ & $\mathrm{H}$ & $\mathrm{H}$ & $\mathrm{N}$ & bis-Phenylsulfonyl \\
$\mathbf{8 6}$ & $\mathrm{H}$ & $\mathrm{H}$ & $\mathrm{N}$ & bis-(4-bromophenylsulfonyl) \\
$\mathbf{8 7}$ & $\mathrm{OCH}_{3}$ & $\mathrm{OCH}_{3}$ & $\mathrm{NHSO}_{2}$ & 4-tert-Butylphenyl \\
$\mathbf{8 8}$ & $\mathrm{H}$ & $\mathrm{H}$ & $\mathrm{NHCO}$ & (E)-Cinnamyl \\
$\mathbf{8 9}$ & $\mathrm{H}$ & $\mathrm{H}$ & $\mathrm{NHCO}$ & 4-Fluoro-2-nitrobenzyl \\
$\mathbf{9 0}$ & $\mathrm{H}$ & $\mathrm{H}$ & $\mathrm{NHCO}$ & 2-Furanyl \\
$\mathbf{9 1}$ & $\mathrm{H}$ & $\mathrm{H}$ & $\mathrm{NHCO}$ & 3-Quinolinyl
\end{tabular}

Figure 14. Sulfonamido derivatives of tariquidar<smiles>COc1ccc(CCNC(=O)c2ccccc2NCc2cn(CCN3CCc4cc(OC)c(OC)cc4C3)nn2)cc1OC</smiles>

Figure 15. Triazole derivatives

In search for more stable analogues, Peña-Solórzano et al ${ }^{[163]}$ prepared a series of tariquidar analogues with chalcone and ketone moieties, according to a bioisosteric approach [Figure 16]. These compounds were investigated for their inhibitory activity and selectivity toward BCRP. The most potent compounds of the two series have a methyl group at the amine chalcone core suggesting the importance of this group in this position. In the chalcones series, correlation between potency and lipophilicity was found, in fact, the most potent compounds showed the highest calculated partition coefficient values. Compound 94, with the highest clogP value (6.97), showed an $\mathrm{IC}_{50}$ value of $0.88 \mu \mathrm{M}$ in the Hoechst assay on BCRP-overexpressing MCF-7/ Topo cells, that is similar to that of reference compound fumitremorgin C (FTC) $(77)\left(\mathrm{IC}_{50}=0.731 \mu \mathrm{M}\right)$. The modulating activities for P-gp and MRP1 were evaluated by calcein assay using Kb-V1 (P-gp) and MDCK II (MRP1) cell lines, respectively. The results suggested that the chalcones series had low inhibitory activity on P-gp and MRP1 both at $1 \mu \mathrm{M}$ and $10 \mu \mathrm{M}$. Ketone series exhibited lower BCRP modulating activity than the chalcone series. The most potent compound of the series, 95 showed an $\mathrm{IC}_{50}$ value of $6.65 \mu \mathrm{M}$ in the Hoechst assay with a small preference for BCRP over P-gp and MRP1, evaluated by calcein assay using Kb-V1 (P$\mathrm{gp})$ and MDCK II (MRP1) cell lines. These results indicated that the lipophilicity plays a critical role for the BCRP modulation and selectivity when comparing the two series of compounds. Compound 94 showed a concentration dependent cytostatic effect on proliferating MCF-7/Topo cells that could be ascribed to the reactive $\alpha-\beta$-unsaturated ketone core. The ketone derivative 95 , which is lacking the Michael acceptor system, showed indeed a reduced cytotoxicity ${ }^{[163]}$.

Tariquidar derivatives with the 6,7-dimethoxy-2-phenethyl-1,2,3,4-tetrahydroisoquinoline group connected to aryl-substituted moieties by amide, ester and alkylamine functions, were investigated for their P-gp, MRP1 and BCRP activity ${ }^{[164]}$ [Figure 17]. 
<smiles>COCCOc1cc2c(cc1OC)CCN(CC(=O)c1ccc(C)c(NC(=O)c3ccc4ccccc4n3)c1)C2</smiles>

Figure 16. Chalcone and ketone derivatives of tariquidar

Compounds containing an amide or alkylamine group generally displayed higher activity values than the corresponding ester derivatives in the calcein-AM test on P-gp overexpressing cells (MDCK-MDR1 cells). However, compounds bearing a 2,2-bis (4-methoxyphenyl) moiety as aryl residue showed the best P-gp activity in all three series with comparable values $\left(96, \mathrm{EC}_{50}=0.30 \mu \mathrm{M} ; 97, \mathrm{EC}_{50}=0.33 \mu \mathrm{M} ; 98, \mathrm{EC}_{50}=0.57\right.$ $\mu \mathrm{M})$. Amide and alkylamine derivatives showed no activity toward both MRP1 and BCRP evaluated by measuring the inhibition of the efflux of calcein-AM in MRP1 overexpressing cells (MDCK-MRP1 cells) and of Hoechst 33342 in BCRP overexpressing cells (MDCK-BCRP cells), respectively. Unusually, the substitution of the amide function with the ester one led to derivatives that showed low activities on BCRP $\left(\mathrm{EC}_{50}\right.$ values between 5.9 and $17 \mu \mathrm{M})$.

All compounds were stable to enzymatic hydrolysis evaluated in human plasma, even those containing an amide or ester group not impairing, therefore, the in vivo bioavailability ${ }^{[164]}$.

\section{OTHERS}

Beside the compounds described previously, other compounds belonging to different chemical classes have been described, both as BCRP selective modulators and as P-gp/BCRP dual modulators.

\section{Tetrahydro- $\beta$-carbolines}

Some derivatives were designed based on Ko143 structure, which presents a tetrahydro- $\beta$-carbolinic scaffold. Since Ko143 (5) exhibits an unfavorable pharmacokinetic profile, probably due to hydrolysis of the ester moiety, Li et al. ${ }^{[165]}$ designed and synthesized some Ko143 derivatives, to explore the structure-activity relationships in this field and to obtain new compounds with a better PK profile. As first, three desmethoxy analogs were prepared; moreover, a series of compounds devoid of the ester group and showing different stereochemistry were obtained [Figure 18]. To determine the inhibitory potency of the new compounds, the $\mathrm{IC}_{50} \mathrm{~s}$ of these derivatives on BCRP mediated E3S (estrone sulfate) transport were measured on Caco-2 cells. Results suggested that the ester portion of the lead compound Ko143 is not necessary for the activity and can be replaced by more stable and simple groups, such as a methyl group. In fact, compounds 99 and 100 showed almost the same potency as that of Ko143 $\left(\mathrm{IC}_{50}\right.$ of Ko143 was determined along with each synthesized compound because of the variability in the determination of the parameter); the diastereoisomers, which present a different configuration at the marked stereocenter [Figure 18], failed to exhibit activity up to $10 \mathrm{M}$. The potency of 99 on P-gp inhibition was also evaluated on Caco-2 cells but, as the lead compound Ko143, it showed an $\mathrm{IC}_{50}>30 \mathrm{M}$, behaving as selective BCRP inhibitor. Both 99 and 100 showed also a better PK profile in rats with respect to Ko143 $3^{[165]}$.

On 99, re-named ML753286, further tests were conducted ${ }^{[166]}$ to characterize the preclinical properties. ML753286 confirmed to be a selective inhibitor for BCRP, without any effect not only on P-gp, but also on organic anion transporting polypeptide and major cytochrome P450s. The compound did not behave as 


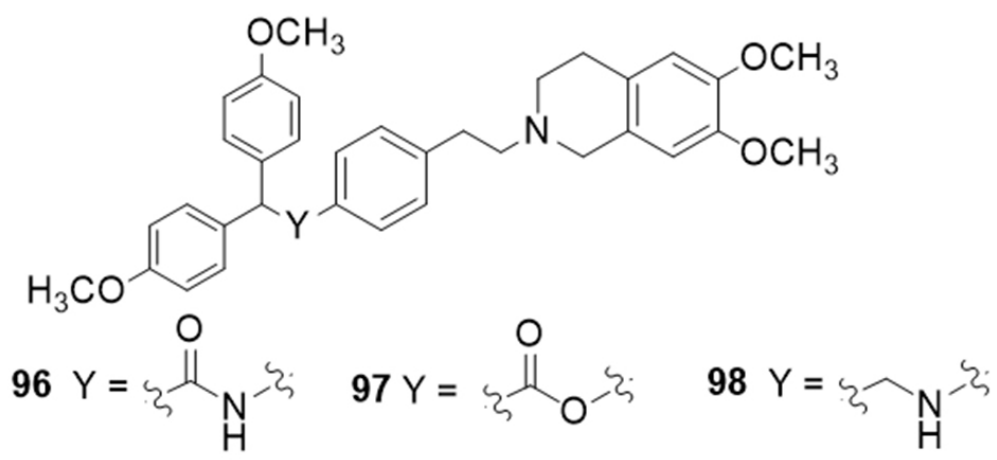

Figure 17. Aryl-substituted derivatives of tariquidar<smiles>[R]c1cc2c3c([nH]c2cc1OC)[C@@H](CC(C)C)N1C[C@@H]3C(=O)N[C@@H](C)C1=O</smiles>

99: $\mathrm{R}=\mathrm{H}(\mathrm{ML753286})$<smiles>COc1ccc2c(c1)[nH]c1c(C)nccc12</smiles>

Harmine<smiles>[R]C(=O)N1CCc2c([nH]c3ccccc23)C1c1ccc(Cl)c(Cl)c1</smiles>

101: $\mathrm{R}_{3}=4-\mathrm{OCH}_{3}$-phenyl 102: $\mathrm{R}_{3}=3-\mathrm{OCH}_{3}$-phenyl

Figure 18. Tetrahydro- $\beta$-carboline derivatives

efflux transporter substrate and showed good in vitro ADME properties. In vivo $\mathrm{PK}$ experiments in mouse and rat confirmed its in vitro potency and identified the optimal dose of ML753286 (50-300 mg/Kg orally) to inhibit Bcrp in rodents ${ }^{[166]}$.

Also the alkaloid harmine [Figure 18] was reported to be an BCRP inhibitor ${ }^{[167]}$. This compound contains the $\beta$-carboline moiety, a substructure like that presented by BCRP inhibitors Ko143 (5) and FTC (77). On this basis, Wiese et al. ${ }^{[168]}$ synthesized 37 new tetrahydro- $\beta$-carboline derivatives with a tricyclic common scaffold and different substituents on the phenyl ring, on the indole nitrogen $\mathrm{N}-9$ and on the N-2 present in the saturated ring. All synthesized compounds were tested for their inhibitory potency toward BCRP using the Hoechst 33342 accumulation assay with Madin-Darby canine kidney II (MDCK II) cells overexpressing the transporter. Some selected compounds were additionally tested in the pheophorbide A assay: the comparison of the pIC50 values obtained in both assays showed a very high correlation. Many compounds were active, and derivatives 101 and 102 displayed the best activity (IC50 $=0.233 \mathrm{M}$ and IC50 $=0.238 \mathrm{M}$ respectively in the Hoechst 33342 assay). SAR suggested that the hydrogen bond donor-acceptor system of the hydrogen at indole N9 and the acyl group at N2 were necessary for the inhibitory activity. Moreover, chlorine or bromine substitution in meta and/or para position at the phenyl ring gave highly potent compounds with an inhibitory activity in the submicromolar range. The pharmacological profile of the two compounds and of some analogs was deepened by evaluating their toxicity, their ability to reverse MDR and their inhibition on ATPase activity ${ }^{[168]}$. Cytotoxicity data show that their inhibitory effect is substantially 
<smiles>CC1=C(C(=O)OCc2ccccn2)C(c2ccc([N+](=O)[O-])cc2)C2=C(CCCC2=O)N1</smiles><smiles>[R]C1=C(C)NC2=C(C(=O)CCC2)C1C(=O)OCCc1ccccn1</smiles>

104: $R=2,4$-dichlorophenyl<smiles>[R]C1C(C(=O)OCCCc2ccccn2)=C(C)NC2=C1C(=O)CCC2O[GaH2]</smiles>

106: $R=3$-chloropheny

Figure 19. 5-Oxo-hexahydroquinoline derivatives

higher than their toxicity, and results confirmed that they are able to reverse the BCRP-mediated resistance toward SN-38 and to inhibit the ATPase activity. All compounds were also screened for ABCB1 inhibition to investigate their selectivity toward BCRP, using the calcein AM assay with the A2780 adr cell line, but most of them showed just a slight effect on $\mathrm{ABCB} 1$ at $10 \mu \mathrm{M}$. The most potent compounds included 101 and 102 showed to be selective BCRP inhibitors.

\section{Other heterocycles and cyclic compounds}

Other heterocycle derivatives were tested as BCRP inhibitors.

Ranjbar et al. ${ }^{[169]}$ described a series of 5-oxo-hexahydroquinolines with pyridyl methyl carboxylate substitutions such as compound 103 [Figure 19] which behaved as P-gp inhibitors.

Based on these results, very recently the same group ${ }^{[170]}$ synthesized twelve 5-oxo-hexahydroquinolines bearing different aromatic substitutions at $\mathrm{C} 4$ while having 2-pyridyl alkyl carboxylate substituents (ethyl or propyl), on the basis of preliminary drug-likeness properties calculation that indicated that all the proposed compounds could be successful oral drug candidates. The inhibitory effects of the compounds on P-gp, MRP1 and BCRP were evaluated by flow cytometric determination of accumulation of rhodamine 123 in, respectively, P-gp-overexpressing MES-SA/DX5 cells, calcein AM in MRP1-overexpressing Flp-In HEK293 cells and mitoxantrone in BCRP-overexpressing HEK293 cells. To confirm the P-gp inhibitory activity, the effect of compounds on the reduction of doxorubicin's IC $_{50}$ on drug-resistant human uterine sarcoma cell line, MES-SA/DX5, was also evaluated ${ }^{[170]}$.

Most of the compounds showed significant inhibition of P-gp transporter and two of them showed an outstanding activity in the doxorubicin resistance reversal. Some of the derivatives were also interesting MRP1 inhibitors, and some of them were efficacious in inhibiting BCRP. Analogs containing chlorine moiety on the phenyl ring, including 104, 105 and 106 [Figure 19] showed multiple modulatory activity being active on both P-gp and BCRP, but also on MRP1 transporter, in inhibiting transporter-mediated efflux of the probe. None of the compounds showed to be a selective inhibitor of BCRP. Interestingly, some of the compounds were able to induce collateral sensitivity, but this effect was MRP1-dependent ${ }^{[170]}$.

Also a series of more than 30 compounds bearing the 9-deazapurine scaffold [Figure 20] were synthesized ${ }^{[171]}$, since it is a substructure present in pyrrolopyrimidines ${ }^{[172]}$ and indolopyrimidines ${ }^{[173]}$ which showed to be transporter inhibitors. Their inhibitory activity on P-gP, MRP1 and BCRP was measured: for P-gp, calcein AM efflux was evaluated in P-gp overexpressing A2780 adr cell line; for MRP1 the daunorubicin assay on H69AR overexpressing MRP1 cells (ATCC CRL-11351) was used; finally, the effect on BCRP was evaluated by the pheophorbide A assay on MDCK II BCRP cells which overexpress this protein.

The obtained 9-deazapurines were classified according to their structure into four classes: compounds belonging to the first three classes were in most cases MRP1 inhibitors or dual MRP1/P-gp inhibitors, 

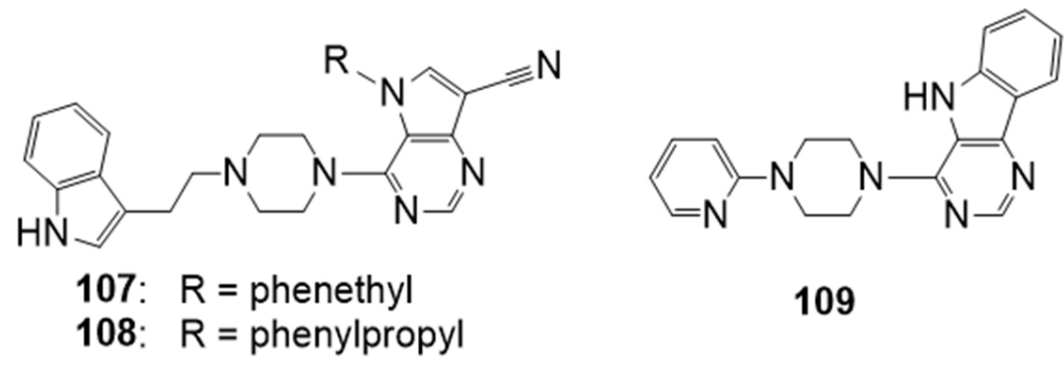

Figure 20. 9-Deazapurine derivatives

showing $\mathrm{IC}_{50} \mathrm{~s}$ in the micromolar or submicromolar range for the latter transporter. However, two compounds belonging to the second class, 107 and 108 [Figure 20], behaved as promising inhibitors toward the three transporters, being active in the low micromolar or in the nanomolar range IC $_{50}$ on P-gp, MRP1 and BCRP 1.64 M, 0.524 M and 1.39 M respectively for 107 and $1.46 \mathrm{M}, 0.501 \mathrm{M}$ and 1.69 $\mathrm{M}$ respectively for 108). In this class, a relationship between side chain length and biological activity in the case of P-gp and BCRP could be observed.

The fourth class was constituted by 8,9-annulated 9-deazapurines. This class showed high affinity in respect to BCRP, with different effects in respect to P-gp and MRP1. The most interesting compound was 109 [Figure 20], a good inhibitor of BCRP but also of P-gp and MRP1 ( $\mathrm{IC}_{50}$ of $1.81 \mu \mathrm{M}, 5.00 \mu \mathrm{M}$ and $0.495 \mu \mathrm{M}$ respectively). Compounds 107, 108 and 109 are triple inhibitors with $\mathrm{IC}_{50} \mathrm{~s}$ in the single-digit micromolar range. Intrinsic toxicity of 108 was further investigated: this derivative showed no or little toxic effect on resistant cell lines overexpressing the three transporters and on the corresponding sensitive cells. Moreover, compound 108 behaved as noncompetitive inhibitor on the three transporters, and was able to restore sensitivity to daunorubicin (P-gp and MRP1) and SN-38 (BCRP) in resistant cells, although only in part in the case of P-gp-overexpressing ones ${ }^{[171]}$.

As stated, a promising w. ay to identify new lead compounds that modulate MDR is the study of natural compounds ${ }^{[174]}$ as macrocyclic diterpenoids. Schäfer et al. ${ }^{[175]}$ described the total synthesis of simplified analogs of gagunin E, a marine homoverrucosanoid isolated in 2002 from a sponge of the genus Phorbas ${ }^{[176]}$. A library of 16 of non-natural homoverrucosanoid-(cyclohepta[e]hydrindanoids) derived esters [Figure 21] were examined as inhibitors of the membrane transporter proteins $A B C B 1, A B C G 2$ and $A B C C 1$, using the calcein $\mathrm{AM}$ accumulation assay on both $\mathrm{ABCB} 1$ overexpressing $\mathrm{A} 2780 \mathrm{adr}$ cells and $\mathrm{ABCC} 1$ overexpressing H69AR cells, and the Hoechst 33342 accumulation assay using the ABCG2 overexpressing MDCK II ABCG2 cell line respectively.

SAR studies revealed that specific structure, configuration and general lipophilicity of the homoverrucosane scaffold are important factors for effective molecular recognition. The presence of an S-configured alcohol at C-6 and a quinoline-6-carboxylic acid ester at C-4 were beneficial for binding to ABCG2 and ABCB1: the quinolinecarboxylate $110\left(\mathrm{IC}_{50}=1.56 \mathrm{M}\right.$ on $\mathrm{ABCG} 2$ and $\mathrm{IC}_{50}=1.39 \mathrm{M}$ on $\left.\mathrm{ABCB} 1\right)$ represented the most potent dual ABCG2/P-gp modulator of the collection; the bromobenzoate 111 instead showed a selective profile, exhibiting a strong inhibitory effect on $\mathrm{ABCG} 2\left(\mathrm{IC}_{50}=2.91 \mathrm{M}\right)$ without affecting $\mathrm{ABCB}$-mediated efflux, and a low cytotoxicity.

\section{Propafenone derivatives}

Continuing a previous research on propafenone derivatives ${ }^{[177]}$, Schwarz et al. ${ }^{[178]}$ synthesized novel propafenones aiming to define the molecular characteristics eliciting transporter selectivity [Figure 22]. 


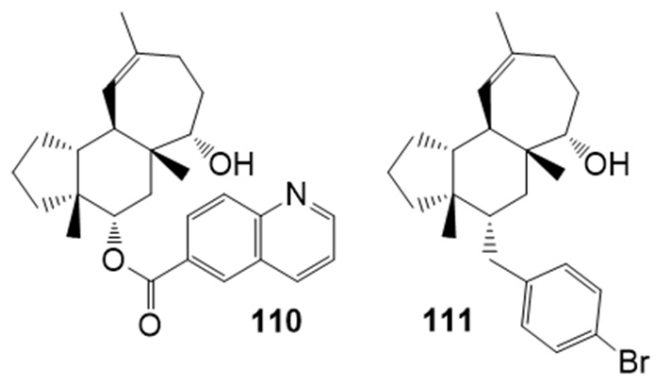

Figure 21. Homoverrucosanoid derivatives<smiles>[R]CC(=O)c1ccc([R2])cc1OCCN[R3]</smiles>

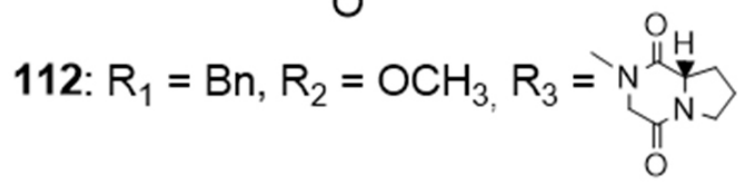<smiles>[R]CC(=O)c1ccc([R2])cc1OCC(O)C[R3]</smiles><smiles>[R]CC(=O)c1ccccc1OC[C@H](O)CN[C@@H]([R4])C</smiles>

Figure 22. Propafenone derivatives

The design of the new derivatives took into consideration two molecular characteristics: the presence of a basic nitrogen atom and the presence of a rigid moiety on the chain, since a non ionizable nitrogen atom, the presence of rotatable bonds and the presence of H-bond acceptors could influence both activity and selectivity. The nature of the spacer connecting the nitrogen atom and the central aromatic ring was modified, the flexibility of substituent $\mathrm{R}_{3}$ [Figure 22] was modified by inserting a proline or a diketopiperazine moiety, the lipophilicity was varied by inserting substituents on different position, and the effect of basicity of the nitrogen atom was evaluated synthesizing some aliphatic $\mathrm{N}$-substituted analogues, as described by the general structures.

The inhibitory activity on P-gp and BCRP was evaluated, measuring the inhibition of the intracellular accumulation of the substrates daunorubicin (P-gp overexpressing cells) or mitoxantrone (BCRP overexpressing cells).

Some of the tested compounds were active as inhibitors of both transporters; only the methoxy substituted compounds $112\left(\mathrm{IC}_{50}=2.3 \mathrm{M}\right.$ on BCRP and $\mathrm{IC}_{50}=6.2 \mathrm{M}$ on P-gp $)$ and $113\left(\mathrm{IC}_{50}=3.8 \mathrm{M}\right.$ on BCRP and $\mathrm{IC}_{50}=$ 11.0 M on P-gp) [Figure 22] carrying a piperazinedione residue were more active on BCRP than on P-gp.

In the meantime, to predict the inhibition against BCRP and P-gp for the designed compounds, two in silico classification models were created. In addition, the $\log \mathrm{P}$ values of all compounds were calculated. Results of the theoretical models were compared with the experimental results. The BCRP- and the P-gp-inhibition model showed different trends; results indicated that both the flexibility of the substituent at the nitrogen 


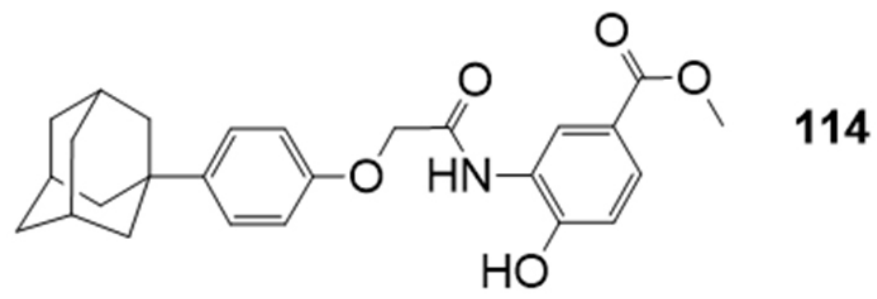

Figure 23. HIF-1 inhibitor

atom, and the basicity of the nitrogen atom, influenced transporter selectivity. Moreover, $\log \mathrm{P}$ values seemed to have a higher influence on the inhibitory activity on P-gp with respect to that on BCRP.

\section{Amide or ester derivatives}

Kim et al. ${ }^{[179]}$ synthesized compound 114 [Figure 23], an inhibitor of the hypoxia inducible factor-1 alpha (HIF-1), which plays an important role in angiogenesis and metastasis and is a promising therapeutic target for the development of anticancer drugs. Additional studies suggested that the compound inhibited HIF-1 stability via direct binding with calcineurin b homologous protein 1 (CHP1).

Recently, the effects of 114 on the functional activity and gene expression of two major efflux transporters, BCRP and P-gp were evaluated ${ }^{[180]}$, by using MDCKII cells overexpressing each transporter (MDCKII-BCRP and MDCKII-MDR1). Its effects on the cytotoxicity of co-administered mitoxantrone and doxorubicin were also evaluated in both MDCKII-mock and MDCKII-BCRP transfected cells: the derivative downregulated BCRP expression and made resistant cells more susceptible to the cytotoxicity of the anticancer drugs. Furthermore, 114 improved the oral exposure of methotrexate by twofold in rats. In contrast to BCRP, the compound had no inhibition effect on cellular accumulation of P-gp substrate rhodamine 123 and gene expression of P-gp, showing to behave as potent and selective BCRP inhibitor.

Continuing their previous researches on derivatives of the natural alkaloid Pervilleine A, and based on the polyvalency approach, Teodori et al. ${ }^{[181]}$ synthesized a set of basic molecules carrying aryl moieties connected to the $\mathrm{N}$-containing linker through ester functions. The nature of the spacer (dicyclohexylamine or dialkylamine) and of the aryl moieties was modified to investigate their interacting mechanism with the $\mathrm{ABC}$ transporters and their selectivity [Figure 24]. To prevent the possible metabolic instability of the ester functions, a little number of derivatives containing the amide group were also studied.

The inhibitory effect on P-gp, MRP1 and BCRP of the synthesized molecules was evaluated, measuring the inhibition of the efflux of Calcein-AM in P-gp overexpressing MDCK-MDR1 cells and in MRP1overexpressing MDCK-MRP1 cells, and of Hoechst 33342 in BCRP-overexpressing MDCK-BCRP cells. All compounds were also tested to evaluate their intrinsic cytotoxicity at $1 \mathrm{M}$. P-gp interacting-mechanism of the derivatives was further investigated by measuring Apparent Permeability $\left(P_{a p p}\right)(\mathrm{BA} / \mathrm{AB})$ in Caco-2 cell monolayer and ATP cell depletion in MDCK-MDR1cells. All dicyclohexylamine derivatives were found to be P-gp substrates, whereas a dialkylamine derivative was a P-gp inhibitor. Replacement of the ester function with the amide one led to compounds that are inactive or poorly active on the transporters.

Among the obtained compounds, the four bis(cyclohexanol)amine geometrical isomers $115^{[182]}$ [Figure 24] bearing trans-3,4,5-trimethoxycinnamyl and 2,2-bis-(4-methoxyphenyl) moieties are particularly interesting because of their clear-cut dependence on stereochemistry for their potency. Among these four geometric isomers, the highest potency was found for the trans/cis isomer $115 \mathrm{~b}$ with activity in the nanomolar range $\left(\mathrm{EC}_{50}=1.2 \mathrm{nM}\right)$. All four isomers were inactive on MRP1 but were active on $\mathrm{BCRP}\left(\mathrm{EC}_{50}\right.$ in the single-digit micromolar range except for the cis/cis isomer). 


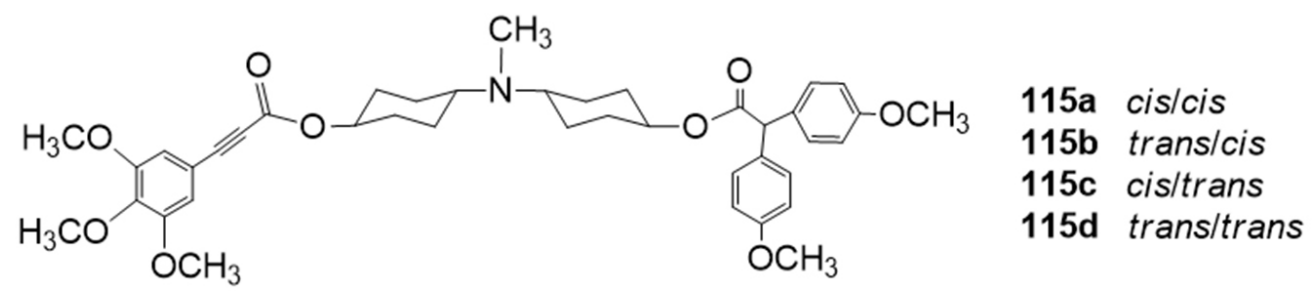<smiles>CN(CCOC(=O)Br)CCOC(=O)Br</smiles>

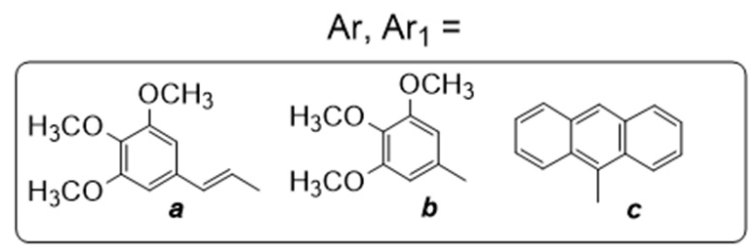

Figure 24. Ester derivative

These results suggested that the nature and the stereochemistry of the spacer influence the interaction binding mode of these derivatives. Moreover, the nature of the aryl moieties influences the selectivity since the set of isomers 115 are P-gp/BCRP modulators inhibitors.

Recently, based on the same approach, the same research group ${ }^{[183]}$ synthesized several $N, N$-bis(alkanol) amine aryl esters characterized by the presence of a basic nitrogen atom linked to two different aromatic ester portions by two polymethylenic chains of variable length as spacers, described by the general structure 116 [Figure 24].

Keeping in mind preceding results ${ }^{[184-186]}$, they synthesized all the possible isomers bearing a combination of chains of variable length, for a total length of 8,9 and 10 methylenes, and carrying different aromatic residues. P-gp inhibiting activity was evaluated on K562/DOX doxorubicin resistant cells, measuring their effect on THP-adriamycin (pirarubicin) nuclear uptake. Results of this preliminary assay indicated that derivatives showing a total spacer of 10 methylenes were always very active, regardless of the combination of aromatic residues and of $n$ and $m$ chain lengths. Chemical stability both in phosphate buffer solution and in human plasma was evaluated, indicating that most of the obtained molecules were stable in both matrices.

Selected molecules were further tested evaluating their effect on rhodamine 123 assay in the resistant K562/DOX cell line. Moreover, the inhibitory effect on P-gp, MRP1 and BCRP was evaluated, measuring the inhibition of the efflux of Calcein-AM in P-gp overexpressing MDCK-MDR1 cells and in MRP1overexpressing MDCK-MRP1 cells, and of Hoechst 33342 in BCRP-overexpressing MDCK-BCRP cells. In these tests, the molecules maintained a good activity on P-gp $\left(\mathrm{EC}_{50}\right.$ comprised between 0.20 and $\left.0.92 \mathrm{M}\right)$ and good or moderate activities on BCRP ( $\mathrm{EC}_{50}$ comprised between 3.0 and $16.0 \mathrm{M}$ ). At the contrary, only derivatives carrying a 3,4,5-trimethoxyphenyl residue [labelled b in Figure 24] together with the trans-3,4,5trimethoxycinnamyl one [labelled a in Figure 24] are active on MRP1, while the other compounds showed no activity in this test. Therefore, this finding suggests that suitable modification of the aromatic moiety can address selectivity among the transporters in this series of molecules. P-gp interacting-mechanism was investigated by measuring Apparent Permeability $\left(P_{a p p}\right)$ in Caco-2 cell monolayer in combination with ATP cell depletion in MDCK-MDR1 cells: two molecules resulted as unambiguous substrates whereas the other compounds behaved as not-transported substrates ${ }^{[187]}$.

\section{Tyrosine kinase inhibitors}

Tyrosine kinase inhibitors (TKIs) are a group of target-specific anticancer drugs. Gefitinib (45) [Figure 10], a representative molecule of this class, was described previously as lead compound. Unfortunately, increasing 
resistance to TKIs has been reported, and the enhanced efflux of these derivatives by overexpression of $\mathrm{ABCB} 1$ and $\mathrm{ABCG} 2$ has been considered as responsible for the resistance. Further studies have indicated that many TKIs behave as dual substrates of P-gp and BCRP or behave as inhibitors. Therefore, TKIs can also act as MDR modulators based on their effect on the transporters. Evaluation of this series of compounds is beyond the aim of this review, but some recent papers describing the inhibition of BCRP or P-gp/BCRP transporters by TKIs are reported ${ }^{[188-191]}$.

\section{CONCLUSIONS}

MDR is a kind of acquired drug resistance to anticancer drugs. This phenomenon is often related to the overexpression of membrane proteins belonging to the $\mathrm{ABC}$ protein family, such as $\mathrm{P}$-gp (ABCB1), BCRP (ABCG2) and MRP1 (ABCC1), which behave as efflux transporters. P-gp is the first transporter discovered to be involved in cancer drug resistance, and over the years, inhibitors of this pump have been disclosed to administer them in combination with chemotherapeutic agents. Three generations of inhibitors of P-gp have been examined in preclinical and clinical studies; however, these trials have failed to demonstrate an improvement in therapeutic efficacy of the co-administered antitumor agent. Nevertheless, the concept that modulation of ABC efflux transporters may overcome MDR is still strong, and the search for new chemosensitizers is still ongoing. Moreover, an intriguing aspect that emerged from the studies was that the ABC transporters P-gp, MRPs and BCRP are often co-expressed in tumors and that they have an overlapped specificity for a variety of substrates. Therefore, selective inhibition of one efflux transporter could be compensated by the remaining transporters, and in the last years many studies were devoted to evaluating the inhibitory activity of new derivatives on cells overexpressing $A B C B 1, A B C C 1$ and ABCG2 respectively.

In the last two decades, after the discovery of BCRP, many new molecules acting as BCRP-dependent MDR modulators were reported. BCRP and P-gp are overexpressed together in several haematological and solid tumours. Moreover, $\mathrm{P}$-gp and $\mathrm{BCRP}$ are the two main $\mathrm{ABC}$ transporters placed at the $\mathrm{BBB}$ and reduce the ability to cross the $\mathrm{BBB}$ of many substrates of these two proteins including chemotherapeutic agents.

On this basis, both selective BCRP inhibitors and dual P-gp/BCRP ones are needed to define sound SARs and to discover new leads for the development of new molecules. As described in the review, many research groups are involved in this field, and many new molecules were reported in the last five years in the literature. Some of them could be promising starting points for the design of new compounds.

\section{DECLARATIONS}

\section{Authors' contributions}

Performed the literature search: Braconi L, Romanelli MN

Elaborated the Figures: Braconi L

Guarantor: Dei S

Wrote and revised the manuscript: Dei S, Teodori E

Reviewed the manuscript: Dei S, Braconi L, Romanelli MN, Teodori E

\section{Availability of data and materials}

Not applicable.

\section{Financial support and sponsorship}

None.

\section{Conflicts of interest}

All authors declared that there are no conflicts of interest. 


\section{Ethical approval and consent to participate}

Not applicable.

\section{Consent for publication}

Not applicable.

\section{Copyright}

(c) The Author(s) 2019.

\section{REFERENCES}

1. Phi LTH, Sari IN, Yang YG, Lee SH, Jun N, et al. Cancer stem cells (CSCs) in drug resistance and their therapeutic implications in cancer treatment. Stem Cells Int 2018;2018:5416923.

2. Longley DB, Johnston PG. Molecular mechanisms of drug resistance. J Pathol 2005;205:275-92.

3. Chien AJ, Moasser MM. Cellular mechanisms of resistance to anthracyclines and taxanes in cancer: intrinsic and acquired. Semin Oncol 2008;35:S1-S14;Quiz S39.

4. Kane SE. Multidrug resistance of cancer cells. in: Testa B, Meyer U, editors. Advances in Drug Research vol.28. New York:Academic Press; 1996: pp. 181-252.

5. Mitscher LA, Pillai SP, Gentry EJ, Shankel DM. Multiple drug resistance. Med Res Rev 1999;19:477-96.

6. Kaye SB. The multidrug resistance phenotype. Br J Cancer 1988;58:691-4.

7. Holohan C, Van Schaeybroeck S, Longley DB, Johnston PG. Cancer drug resistance: an evolving paradigm. Nat Rev Cancer 2013;13:714-726.

8. Kartal-Yandim M, Adan-Gokbulut A, Baran Y. Molecular mechanisms of drug resistance and its reversal in cancer. Crit Rev Biotechnol 2016,36:716-26.

9. Fojo T, Bates S. Strategies for reversing drug resistance. Oncogene 2003;22:7512-23.

10. Raz S, Sheban D, Gonen N, Stark M, Berman B, et al. Severe hypoxia induces complete antifolate resistance in carcinoma cells due to cell cycle arrest. Cell Death Dis 2014,5:e1067.

11. Zhou X, Li D, Wang X, Zhang B, Zhu H, et al. Galectin-1 is overexpressed in CD133+ human lung adenocarcinoma cells and promotes their growth and invasiveness. Oncotarget 2015,6:3111-22.

12. Bosch I, Croop J. P-glycoprotein multidrug resistance and cancer. Biochim Biophys Acta 1996;1288:F37-54.

13. Hrycyna CA, Gottesman MM. Multidrug ABC transporters from bacteria to man: an emerging hypothesis for the universality of molecular mechanism and function. Drug Resist Updat 1998;1:81-3.

14. Gottesman MM, Fojo T, Bates SE. Multidrug resistance in cancer: role of ATP-dependent transporters. Nat Rev Cancer 2002;2:48-58.

15. Chen Z, Shi T, Zhang L, Zhu P, Deng M, et al. Mammalian drug efflux transporters of the ATP binding cassette (ABC) family in multidrug resistance: A review of the past decade. Cancer Lett 2016;370:153-64.

16. El-Awady R, Saleh E, Hashim A, Soliman N, Dallah A, et al. The role of eukaryotic and prokaryotic ABC transporter family in failure of chemotherapy. Front Pharmacol 2017;7:535.

17. Trock BJ, Leonessa F, Clarke R. Multidrug resistance in breast cancer: a meta-analysis of MDR1/gp170 expression and its possible functional significance. J Natl Cancer Inst 1997;89:917-31.

18. Dean M. ABC transporters, drug resistance, and cancer stem cells. J Mammary Gland Biol Neoplasia 2009;14:3-9.

19. Borst P, Elferink RO. Mammalian ABC transporters in health and disease. Annu Rev Biochem 2002;71:537-92.

20. Schinkel AH, Jonker JW. Mammalian drug efflux transporters of the ATP binding cassette (ABC) family: an overview. Adv Drug Deliv Rev 2003;55:3-29.

21. Ho RH, Kim RB. Transporters and drug therapy: implications for drug disposition and disease. Clin Pharmacol Ther 2005;78:260-77.

22. Tarling EJ, de Aguiar Vallim TQ, Edwards PA. Role of ABC transporters in lipid transport and human disease. Trends Endocrinol Metab 2013;24:342-50.

23. Cant N, Pollock N, Ford RC. CFTR structure and cystic fibrosis. Int J Biochem Cell Biol 2014;52:15-25.

24. Gottesman MM, Pastan I. Biochemistry of multidrug resistance mediated by the multidrug transporter. Annu Rev Biochem 1993;62:385427.

25. Rosenberg MF, Callaghan R, Ford RC, Higgins CF. Structure of the multidrug resistance P-glycoprotein to $2.5 \mathrm{~nm}$ resolution determined by electron microscopy and image analysis. J Biol Chem 1997;272:10685-94.

26. Callaghan R, Luk F, Bebawy M. Inhibition of the multidrug resistance P-glycoprotein: time for a change in strategy? Drug Metab Dispos 2014;42:623-631.

27. Müller M, de Vries EG, Jansen PL. Role of multidrug resistance protein (MRP) in glutathione S-conjugate transport in mammalian cells. J Hepatol 1996;24:100-8.

28. Baiceanu E, Nguyen KA, Gonzalez-Lobato L, Nasr R, Baubichon-Cortay H, et al. 2-Indolylmethylenebenzofuranones as first effective inhibitors of ABCC2. Eur J Med Chem 2016;122:408-18.

29. Lage H, Dietel M. Effect of the breast-cancer resistance protein on atypical multidrug resistance. Lancet Oncol 2000;1:169-75. 
30. Kawabata S, Oka M, Shiozawa K, Tsukamoto K, Nakatomi K, et al. Breast cancer resistance protein directly confers SN-38 resistance of lung cancer cells. Biochem Biophys Res Commun 2001;280:1216-23.

31. Horsey AJ, Cox MH, Sarwat S, Kerr ID. The multidrug transporter ABCG2: still more questions than answers. Biochem Soc Trans 2016;44:824-30.

32. Rosenberg MF, Kamis AB, Callaghan R, Higgins CF, Ford RC. Three-dimensional structures of the mammalian multidrug resistance P-glycoprotein demonstrate major conformational changes in the transmembrane domains upon nucleotide binding. $\mathrm{J}$ Biol Chem 2003;278:8294-9.

33. Wu Yj, Wang C, Wei W. The effects of DMARDs on the expression and function of P-gp, MRPs, BCRP in the treatment of autoimmune diseases. Biomed Pharmacother. 2018;105:870-8.

34. Jardetzky O. Simple allosteric model for membrane pumps. Nature 1966;211:969-70.

35. Senior AE, al-Shawi MK, Urbatsch IL. The catalytic cycle of P-glycoprotein. FEBS Lett 1995;377:285-9.

36. Higgins CF, Linton KJ. The ATP switch model for ABC transporters. Nat Struct Mol Biol 2004;11:918-26.

37. Siarheyeva A, Liu R, Sharom FJ. Characterization of an asymmetric occluded state of P-glycoprotein with two bound nucleotides: implications for catalysis. J Biol Chem 2010;285:7575-86.

38. Dawson RJ, Locher KP. Structure of a bacterial multidrug ABC transporter. Nature 2006;443:180-5.

39. Ward A, Reyes CL, Yu J, Roth CB, Chang G. Flexibility in the ABC transporter MsbA: Alternating access with a twist. Proc Natl Acad Sci U S A 2007;104:19005-10.

40. Sharom FJ. The P-glycoprotein multidrug transporter. Essays Biochem 2011;50:161-78.

41. Li J, Jaimes KF, Aller SG. Refined structures of mouse P-glycoprotein. Protein Sci 2014;23:34-46.

42. Cole SP. Targeting multidrug resistance protein 1 (MRP1, ABCC1): past, present, and future. Annu Rev Pharmacol Toxicol 2014;54:95117.

43. Abele R, Tampé R. Peptide trafficking and translocation across membranes in cellular signaling and self-defense strategies. Curr Opin Cell Biol 2009;21:508-15.

44. Loo TW, Clarke DM. The packing of the transmembrane segments of human multidrug resistance P-glycoprotein is revealed by disulfide cross-linking analysis. J Biol Chem 2000;275:5253-6.

45. Pinkett HW, Lee AT, Lum P, Locher KP, Rees DC. An inward-facing conformation of a putative metal-chelate-type ABC transporter. Science 2007;315:373-7.

46. Bolhuis H, van Veen HW, Molenaar D, Poolman B, Driessen AJ, et al. Multidrug resistance in Lactococcus lactis: evidence for ATPdependent drug extrusion from the inner leaflet of the cytoplasmic membrane. EMBO J 1996;15:4239-45.

47. Wilkens S. Structure and mechanism of ABC transporters. F1000Prime Rep 2015;7:14.

48. Juliano RL, Ling V. A surface glycoprotein modulating drug permeability in Chinese hamster ovary cell mutants. Biochim Biophys Acta 1976;455:152-62.

49. Jones PM, George AM. A new structural model for P-glycoprotein. J Membr Biol 1998;166:133-147.

50. Ho GT, Moodie FM, Satsangi J. Multidrug resistance 1 gene (P-glycoprotein 170): an important determinant in gastrointestinal disease? Gut 2003;52:759-66.

51. Loo TW, Clarke DM. Merck Frosst Award Lecture 1998. Molecular dissection of the human multidrug resistance P-glycoprotein. Biochem Cell Biol 1999;77:11-23.

52. Jones PM, George AM. Symmetry and structure in P-glycoprotein and ABC transporters what goes around comes around. Eur J Biochem 2000;267:5298-305.

53. Aller SG, Yu J, Ward A, Weng Y, Chittaboina S, et al. Structure of P-glycoprotein reveals a molecular basis for poly-specific drug binding. Science 2009;323:1718-22.

54. Choi YH, Yu AM. ABC transporters in multidrug resistance and pharmacokinetics, and strategies for drug development. Curr Pharm Des 2014;20:793-807.

55. Choudhuri S, Klaassen CD. Structure, function, expression, genomic organization, and single nucleotide polymorphisms of human ABCB1 (MDR1), ABCC (MRP), and ABCG2 (BCRP) efflux transporters. Int J Toxicol 2006;25:231-59.

56. Sharom FJ. ABC multidrug transporters: structure, function and role in chemoresistance. Pharmacogenomics 2008;9:105-27.

57. Cole SP, Bhardwaj G, Gerlach JH, Mackie JE, Grant CE, et al. Overexpression of a transporter gene in a multidrug-resistant human lung cancer cell line. Science 1992;258:1650-4.

58. Cole SP, Deeley RG. Multidrug resistance-associated protein: sequence correction. Science 1993;260:879.

59. McGrath T, Center MS. Mechanisms of multidrug resistance in HL60 cells: evidence that a surface membrane protein distinct from P-glycoprotein contributes to reduced cellular accumulation of drug. Cancer Res 1988;48:3959-63.

60. Cole SPC, Sparks KE, Fraser K, Loe DW, Grant CE, et al. Pharmacological characterization of multidrug resistant MRP-transfected human tumor cells. Cancer Res 1994;54: 5902-10.

61. Ozben T. Mechanisms and strategies to overcome multiple drug resistance in cancer. FEBS Lett 2006;580:2903-9.

62. Rappa G, Lorico A, Flavell RA, Sartorelli AC. Evidence that the multidrug resistance protein (MRP) functions as a co-transporter of glutathione and natural product toxins. Cancer Res 1997;57:5232-7.

63. Renes J, de Vries EG, Nienhuis EF, Jansen PL, Müller M. ATP- and glutathione-dependent transport of chemotherapeutic drugs by the multidrug resistance protein MRP1. Br J Pharmacol 1999;126:681-8.

64. Ween MP, Armstrong MA, Oehler MK, Ricciardelli C. The role of ABC transporters in ovarian cancer progression and chemoresistance. Crit Rev Oncol Hematol 2015;96:220-56. 
65. Krizkova V, Dubova M, Susova S, Vycital O, Bruha J, et al. Protein expression of ATP-Binding cassette transporters ABCC10 and ABCC11 associates with survival of colorectal cancer patients. Cancer Chemother Pharmacol 2016;78:595-603.

66. Doyle LA, Yang W, Abruzzo LV, Krogmann T, Gao Y, et al. A multidrug resistance transporter from human MCF-7 breast cancer cells. Proc Natl Acad Sci USA 1998;95:15665-70.

67. Miyake K, Mickley L, Litman T, Zhan Z, Robey R, et al. Molecular cloning of cDNAs which are highly overexpressed in mitoxantroneresistant cells: demonstration of homology to ABC transport genes. Cancer Res 1999;59:8-13.

68. Kage K, Tsukahara S, Sugiyama T, Asada S, Ishikawa E, et al. Dominant-negative inhibition of breast cancer resistance protein as drug efflux pump through the inhibition of S-S dependent homodimerization. Int J Cancer 2002;97:626-30.

69. Polgar O, Robey RW, Bates SE. ABCG2: structure, function and role in drug response. Expert Opin Drug Metab Toxicol 2008;4:1-15.

70. Wang H, Lee EW, Cai X, Ni Z, Zhou L, et al. Membrane topology of the human breast cancer resistance protein (BCRP/ABCG2) determined by epitope insertion and immunofluorescence. Biochemistry 2008;47:13778-87.

71. Wong K, Briddon SJ, Holliday ND, Kerr ID. Plasma membrane dynamics and tetrameric organisation of ABCG2 transporters in mammalian cells revealed by single particle imaging techniques. Biochim Biophys Acta 2016;1863:19-29.

72. Nakanishi T, Ross DD. Breast cancer resistance protein (BCRP/ABCG2): its role in multidrug resistance and regulation of its gene expression. Chin J Cancer 2012;31:73-99.

73. Fletcher J, Haber M, Henderson MJ, Norris MD. ABC transporters in cancer: more than just drug efflux pumps. Nat Rev Cancer 2010;10:147-56.

74. Haber M, Smith J, Bordow SB, Flemming C, Cohn SL, et al. Association of high-level MRPl expression with poor clinical outcome in a large prospective study of primary neuroblastoma. J Clin Oncol 2006;24:1546-53.

75. Schaich M, Soucek S, Thiede C, Ehninger G, Illmer T. MDR1 and MRP1 gene expression are independent predictors for treatment outcome in adult acute myeloid leukaemia. Br J Haematol 2005;128:324-32.

76. Suvannasankha A, Minderman H, O’Loughlin KL, Nakanishi T, Ford LA, et al. Breast cancer resistance protein (BCRP/MXR/ABCG2) in adult acute lymphoblastic leukaemia: frequent expression and possible correlation with shorter disease-free survival. Br J Haematol 2004; $127: 392-8$.

77. Yoh K, Ishii G, Yokose T, Minegishi Y, Tsuta K, et al. Breast cancer resistance protein impacts clinical outcome in platinum-based chemotherapy for advanced non-small cell lung cancer. Clin Cancer Res 2004;10:1691-7.

78. Damiani D, Tiribelli M, Calistri E, Geromin A, Chiarvesio A, et al. The prognostic value of P-glycoprotein (ABCB) and breast cancer resistance protein (ABCG2) in adults with de novo acute myeloid leukemia with normal karyotype. Haematologica 2006;91:825-8.

79. Li W, Zhang H, Assaraf YG, Zhao K, Xu X, et al. Overcoming ABC transporter-mediated multidrug resistance: molecular mechanisms and novel therapeutic drug strategies. Drug Resist Updat 2016;27:14-29.

80. Kathawala RJ, Gupta P, Ashby CR Jr, Chen ZS. The modulation of ABC transporter-mediated multidrug resistance in cancer: a review of the past decade. Drug Resist Updat 2015;18:1-17.

81. Robert J, Jarry C. Multidrug resistance reversal agents. J Med Chem 2003;46:4805-17.

82. Tsuruo T, Iida H, Tsukagoshi S, Sakurai Y. Overcoming of vincristine resistance in P388 leukemia in vivo and in vitro through enhanced cytotoxicity of vincristine and vinblastine by verapamil. Cancer Res 1981;41:1967-72.

83. Szakács G, Paterson JK, Ludwig JA, Booth-Genthe C, Gottesman MM. Targeting multidrug resistance in cancer. Nat Rev Drug Discov 2006;5:219-34.

84. Palmeira A, Sousa E, Vasconcelos MH, Pinto MM. Three decades of P-gp inhibitors: skimming through several generations and scaffolds. Curr Med Chem 2012;19:1946-2025.

85. Waghray D, Zhang Q. Inhibit or evade multidrug resistance P-glycoprotein in cancer treatment. J Med Chem 2018;61:5108-21.

86. Wilson WH, Jamis-Dow C, Bryant G, Balis FM, Klecker RW, et al. Phase I and pharmacokinetic study of the multidrug resistance modulator dexverapamil with EPOCH chemotherapy. J Clin Oncol 1995;13:1985-94.

87. Minderman H, O'Loughlin KL, Pendyala L, Baer MR. VX-710 (biricodar) increases drug retention and enhances chemosensitivity in resistant cells overexpressing P-glycoprotein, multidrug resistance protein, and breast cancer resistance protein. Clin Cancer Res 2004;10:1826-34.

88. Tidefelt U, Liliemark J, Gruber A, Liliemark E, Sundman-Engberg B, et al. P-glycoprotein inhibitor valspodar (PSC 833) increases the intracellular concentrations of daunorubicin in vivo in patients with P-glycoprotein-positive acute myeloid leukemia. J Clin Oncol 2000;18:1837-44.

89. Lhommé C, Joly F, Walker JL, Lissoni AA, Nicoletto MO, et al. Phase III study of valspodar (PSC 833) combined with paclitaxel and carboplatin compared with paclitaxel and carboplatin alone in patients with stage IV or suboptimally debulked stage III epithelial ovarian cancer or primary peritoneal cancer. J Clin Oncol 2008;26:2674-82.

90. Kolitz JE, George SL, Marcucci G, Vij R, Powell BL, et al. P-glycoprotein inhibition using valspodar (PSC-833) does not improve outcomes for patients younger than age 60 years with newly diagnosed acute myeloid leukemia: Cancer and Leukemia Group B study 19808. Blood 2010;116:1413-21.

91. Luurtsema G, Schuit RC, Klok RP, Verbeek J, Leysen JE, et al. Evaluation of [11C.laniquidar as a tracer of P-glycoprotein: radiosynthesis and biodistribution in rats. Nucl Med Biol 2009;36:643-9.

92. Chi KN, Chia SK, Dixon R, Newman MJ, Wacher VJ, et al. A phase I pharmacokinetic study of the P-glycoprotein inhibitor, ONT-093, in combination with paclitaxel in patients with advanced cancer. Invest New Drugs 2005;23:311-5.

93. Kemper EM, Cleypool C, Boogerd W, Beijnen JH, van Tellingen O. The influence of the P-glycoprotein inhibitor zosuquidar trihydrochloride (LY335979) on the brain penetration of paclitaxel in mice. Cancer Chemother Pharmacol 2004;53:173-8. 
94. Dörner B, Kuntner C, Bankstahl JP, Bankstahl M, Stanek J, et al. Synthesis and small-animal positron emission tomography evaluation of [11C]-elacridar as a radiotracer to assess the distribution of P-glycoprotein at the blood-brain barrier. J Med Chem 2009;52:6073-82.

95. Fox E, Bates SE. Tariquidar (XR9576): a P-glycoprotein drug efflux pump inhibitor. Expert Rev Anticancer Ther 2007;7:447-59.

96. Guns ES, Denyssevych T, Dixon R, Bally MB, Mayer L. Drug interaction studies between paclitaxel (Taxol) and OC144-093--a new modulator of MDR in cancer chemotherapy. Eur J Drug Metab Pharmacokinet 2002;27:119-26.

97. Stewart A, Steiner J, Mellows G, Laguda B, Norris D, et al. Phase I trial of XR9576 in healthy volunteers demonstrates modulation of P-glycoprotein in CD56+ lymphocytes after oral and intravenous administration. Clin Cancer Res 2000;6:4186-91.

98. Darby RA, Callaghan R, McMahon RM. P-glycoprotein inhibition: the past, the present and the future. Curr Drug Metab 2011;12:722-31.

99. Coley HM. Overcoming multidrug resistance in cancer: clinical studies of P-glycoprotein inhibitors. Methods Mol Biol 2010;596:341-58.

100. Cripe LD, Uno H, Paietta EM, Litzow MR, Ketterling RP, et al. Zosuquidar, a novel modulator of P-glycoprotein, does not improve the outcome of older patients with newly diagnosed acute myeloid leukemia: a randomized, placebo-controlled trial of the Eastern Cooperative Oncology Group 3999. Blood 2010;116:4077-85.

101. Kelly RJ, Draper D, Chen CC, Robey RW, Figg WD, et al. A pharmacodynamic study of docetaxel in combination with the P-glycoprotein antagonist tariquidar (XR9576) in patients with lung, ovarian, and cervical cancer. Clin Cancer Res 2011;17:569-80.

102. Karthikeyan S, Hoti SL. Development of fourth generation ABC inhibitors from natural products: a novel approach to overcome cancer multidrug resistance. Anticancer Agents Med Chem 2015;15:605-15.

103. Ceballos MP, Rigalli JP, Cere LI, Semeniuk M, Catania VA, Ruiz ML. ABC transporters: Regulation and association with multidrug resistance in hepatocellular carcinoma and colorectal carcinoma. Curr Med Chem 2018;25:1-26.

104. Ginwala R, Bhavsar R, Chigbu DI, Jain P, Khan ZK. Potential Role of Flavonoids in Treating Chronic Inflammatory Diseases with a Special Focus on the Anti-Inflammatory Activity of Apigenin. Antioxidants (Basel) 2019;8:pii:E35.

105. Morris ME, Zhang S. Flavonoid-drug interactions: effects of flavonoids on ABC transporters. Life Sci 2006;78:2116-30.

106. Peña-Solórzano D, Stark SA, König B, Sierra CA, Ochoa-Puentes C. ABCG2/BCRP: Specific and Nonspecific Modulators. Med Res Rev 2017;37:987-1050.

107. Kiemlian Kwee J. Yin and Yang of Polyphenols in Cancer Prevention: A Short Review. Anticancer Agents Med Chem 2016;16:832-40.

108. Pick A, Müller H, Mayer R, Haenisch B, Pajeva IK, et al. Structure-activity relationships of flavonoids as inhibitors of breast cancer resistance protein (BCRP). Bioorg Med Chem 2011;19:2090-102.

109. Zhang S, Wang X, Sagawa K, Morris ME. Flavonoids chrysin and benzoflavone, potent breast cancer resistance protein inhibitors, have no significant effect on topotecan pharmacokinetics in rats or mdr1a/1b (-/-) mice. Drug Metab Dispos 2005;33:341-8.

110. Yuan J, Wong IL, Jiang T, Wang SW, Liu T, et al. Synthesis of methylated quercetin derivatives and their reversal activities on P-gp- and BCRP-mediated multidrug resistance tumour cells. Eur J Med Chem 2012;54:413-22.

111. Ahmed-Belkacem A, Pozza A, Macalou S, Pérez-Victoria JM, Boumendjel A, et al. Inhibitors of cancer cell multidrug resistance mediated by breast cancer resistance protein (BCRP/ABCG2). Anticancer Drugs 2006;17:239-43.

112. Imai Y, Tsukahara S, Asada S, Sugimoto Y. Phytoestrogens/flavonoids reverse breast cancer resistance protein/ABCG2-mediated multidrug resistance. Cancer Res 2004;64:4346-52.

113. An G, Morris ME. Effects of single and multiple flavonoids on BCRP-mediated accumulation, cytotoxicity and transport of mitoxantrone in vitro. Pharm Res 2010;27:1296-308.

114. Zhang S, Yang X, Morris ME. Flavonoids are inhibitors of breast cancer resistance protein (ABCG2)-mediated transport. Mol Pharmacol 2004;65:1208-16.

115. Hadjeri M, Barbier M, Ronot X, Mariotte AM, Boumendjel A, et al. Modulation of P-glycoprotein-mediated multidrug resistance by flavonoid derivatives and analogues. J Med Chem 2003;46:2125-31.

116. Juvale K, Stefan K, Wiese M. Synthesis and biological evaluation of flavones and benzoflavones as inhibitors of BCRP/ABCG2. Eur J Med Chem 2013;67:115-26.

117. Gallus J, Juvale K, Wiese M. Characterization of 3-methoxy flavones for their interaction with ABCG2 as suggested by ATPase activity. Biochim Biophys Acta 2014;1838:2929-38.

118. Valdameri G, Genoux-Bastide E, Peres B, Gauthier C, Guitton J, et al. Substituted chromones as highly potent nontoxic inhibitors, specific for the breast cancer resistance protein. J Med Chem 2012;55:966-70.

119. Winter E, Lecerf-Schmidt F, Gozzi G, Peres B, Lightbody M, et al. Structure-activity relationships of chromone derivatives toward the mechanism of interaction with and inhibition of breast cancer resistance protein ABCG2. J Med Chem 2013;56:9849-60.

120. Pires ADRA, Lecerf-Schmidt F, Guragossian N, Pazinato J, Gozzi GJ, et al. New, highly potent and non-toxic, chromone inhibitors of the human breast cancer resistance protein ABCG2. Eur J Med Chem 2016;122:291-301.

121. van Loevezijn A, Allen JD, Schinkel AH, Koomen GJ. Inhibition of BCRP-mediated drug efflux by fumitremorgin-type indolyl diketopiperazines. Bioorg Med Chem Lett 2001;11:29-32.

122. Allen JD, van Loevezijn A, Lakhai JM, van der Valk M, van Tellingen O, et al. Potent and specific inhibition of the breast cancer resistance protein multidrug transporter in vitro and in mouse intestine by a novel analogue of fumitremorgin C. Mol Cancer Ther 2002;1:417-25.

123. Han Y, Riwanto M, Go ML, Ee PL. Modulation of breast cancer resistance protein (BCRP/ABCG2) by non-basic chalcone analogues. Eur J Pharm Sci 2008;35:30-41.

124. Boumendjel A, McLeer-Florin A, Champelovier P, Allegro D, Muhammad D, et al. A novel chalcone derivative which acts as a microtubule depolymerising agent and an inhibitor of P-gp and BCRP in in-vitro and in-vivo glioblastoma models. BMC Cancer 2009;9:242. 
125. Juvale K, Pape VF, Wiese M. Investigation of chalcones and benzochalcones as inhibitors of breast cancer resistance protein. Bioorg Med Chem 2012;20:346-55.

126. Valdameri G, Gauthier C, Terreux R, Kachadourian R, Day BJ, et al. Investigation of chalcones as selective inhibitors of the breast cancer resistance protein: critical role of methoxylation in both inhibition potency and cytotoxicity. J Med Chem 2012;55:3193-200.

127. Winter E, Devantier Neuenfeldt P, Chiaradia-Delatorre LD, Gauthier C, Yunes RA, et al. Symmetric bis-chalcones as a new type of breast cancer resistance protein inhibitors with a mechanism different from that of chromones. J Med Chem 2014;57:2930-41.

128. Winter E, Gozzi GJ, Chiaradia-Delatorre LD, Daflon-Yunes N, Terreux R, et al. Quinoxaline-substituted chalcones as new inhibitors of breast cancer resistance protein ABCG2: polyspecificity at B-ring position. Drug Des Devel Ther 2014;8:609-19.

129. Kraege S, Stefan K, Juvale K, Ross T, Willmes T, et al. The combination of quinazoline and chalcone moieties leads to novel potent heterodimeric modulators of breast cancer resistance protein (BCRP/ABCG2). Eur J Med Chem 2016;117:212-29.

130. Juvale K, Gallus J, Wiese M. Investigation of quinazolines as inhibitors of breast cancer resistance protein (ABCG2). Bioorg Med Chem 2013;21:7858-73.

131. Stefan K. Untersuchung von chalkonen und flavonoiden als BCRP-inhibitoren (Master thesis), University of Bonn, 2011.

132. Kraege S, Köhler SC, Wiese M. Acryloylphenylcarboxamides: a new class of breast cancer resistance protein (ABCG2) modulators. ChemMedChem 2016;11:2422-35.

133. Kraege S, Stefan K, Köhler SC, Wiese M. Optimization of acryloylphenylcarboxamides as inhibitors of ABCG2 and comparison with acryloylphenylcarboxylates. ChemMedChem 2016;11:2547-58.

134. Silbermann K, Shah CP, Sahu NU, Juvale K, Stefan SM, et al. Novel chalcone and flavone derivatives as selective and dual inhibitors of the transport proteins ABCB1 and ABCG2. Eur J Med Chem 2019;164:193-213.

135. Chang JB, Wang Q, Li YF. Synthesis and biological activity of Wuweizisu C and analogs. Curr Top Med Chem 2009;9:1660-75.

136. Jin J, Sun H, Wei H, Liu G. The anti-hepatitis drug DDB chemosensitizes multidrug resistant cancer cells in vitro and in vivo by inhibiting P-gp and enhancing apoptosis. Invest New Drugs 2007;25:95-105.

137. Gu X, Ren Z, Tang X, Peng H, Ma Y, et al. Synthesis and biological evaluation of bifendate-chalcone hybrids as a new class of potential P-glycoprotein inhibitors. Bioorg Med Chem 2012;20:2540-8.

138. Gu X, Ren Z, Peng H, Peng S, Zhang Y. Bifendate-chalcone hybrids: a new class of potential dual inhibitors of P-glycoprotein and breast cancer resistance protein. Biochem Biophys Res Commun 2014;455:318-22.

139. Gu X, Ren Z, Tang X, Peng H, Zhao Q, et al. Synthesis and biological evaluation of novel bifendate derivatives bearing 6,7-dihydrodibenzo[c,e]azepine scaffold as potent P-glycoprotein inhibitors. Eur J Med Chem 2012;51:137-44.

140. Gu X, Tang X, Zhao Q, Peng H, Peng S, et al. Discovery of alkoxyl biphenyl derivatives bearing dibenzo[c,e.azepine scaffold as potential dual inhibitors of P-glycoprotein and breast cancer resistance protein. Bioorg Med Chem Lett 2014;24:3419-21.

141. Anuchapreeda S, Leechanachai P, Smith MM, Ambudkar SV, Limtrakul PN. Modulation of P-glycoprotein expression and function by curcumin in multidrug-resistant human KB cells. Biochem Pharmacol 2002;64:573-82.

142. Chearwae W, Anuchapreeda S, Nandigama K, Ambudkar SV, Limtrakul P. Biochemical mechanism of modulation of human P-glycoprotein (ABCB1) by curcumin I, II, and III purified from Turmeric powder. Biochem Pharmacol 2004;68:2043-52.

143. Chearwae W, Shukla S, Limtrakul P, Ambudkar SV. Modulation of the function of the multidrug resistance-linked ATP-binding cassette transporter ABCG2 by the cancer chemopreventive agent curcumin. Mol Cancer Ther 2006;5:1995-2006.

144. Murakami M, Ohnuma S, Fukuda M, Chufan EE, Kudoh K, et al. Synthetic Analogs of Curcumin Modulate the Function of Multidrug Resistance-Linked ATP-Binding Cassette Transporter ABCG2. Drug Metab Dispos 2017;45:1166-77.

145. Pick A, Wiese M. Tyrosine kinase inhibitors influence ABCG2 expression in EGFR-positive MDCK BCRP cells via the PI3K/Akt signaling pathway. ChemMedChem 2012;7:650-62.

146. Krapf MK, Wiese M. Synthesis and Biological Evaluation of 4-Anilino-quinazolines and -quinolines as Inhibitors of Breast Cancer Resistance Protein (ABCG2). J Med Chem 2016;59:5449-61.

147. Krapf MK, Gallus J, Wiese M. Synthesis and biological investigation of 2,4-substituted quinazolines as highly potent inhibitors of breast cancer resistance protein (ABCG2). Eur J Med Chem 2017;139:587-611.

148. Krapf MK, Gallus J, Wiese M. 4-Anilino-2-pyridylquinazolines and -pyrimidines as Highly Potent and Nontoxic Inhibitors of Breast Cancer Resistance Protein (ABCG2). J Med Chem 2017;60:4474-95.

149. Roe M, Folkes A, Ashworth P, Brumwell J, Chima L, et al. Reversal of P-glycoprotein mediated multidrug resistance by novel anthranilamide derivatives. Bioorg Med Chem Lett 1999;9:595-600.

150. Martin C, Berridge G, Mistry P, Higgins C, Charlton P, et al. The molecular interaction of the high affinity reversal agent XR9576 with P-glycoprotein. Br J Pharmacol 1999;128:403-11.

151. Pusztai L, Wagner P, Ibrahim N, Rivera E, Theriault R, et al. Phase II study of tariquidar, a selective P-glycoprotein inhibitor, in patients with chemotherapy-resistant, advanced breast carcinoma. Cancer 2005;104:682-91.

152. Pick A, Klinkhammer W, Wiese M. Specific inhibitors of the breast cancer resistance protein (BCRP). ChemMedChem 2010;5:14981505 .

153. Pajeva IK, Wiese M. Structure-activity relationships of tariquidar analogs as multidrug resistance modulators. AAPS J 2009;11:435-44.

154. Marighetti F, Steggemann K, Hanl M, Wiese M. Synthesis and quantitative structure-activity relationships of selective BCRP inhibitors. ChemMedChem 2013;8:125-35.

155. Marighetti F, Steggemann K, Karbaum M, Wiese M. Scaffold identification of a new class of potent and selective BCRP inhibitors. ChemMedChem 2015;10:742-51.

156. Kwak JO, Lee SH, Lee GS, Kim MS, Ahn YG, et al. Selective inhibition of MDR1 (ABCB1) by HM30181 increases oral bioavailability 
and therapeutic efficacy of paclitaxel. Eur J Pharmacol 2010;627:92-8.

157. Köhler SC, Wiese M. HM30181 Derivatives as Novel Potent and Selective Inhibitors of the Breast Cancer Resistance Protein (BCRP/ ABCG2). J Med Chem 2015;58:3910-21.

158. Köhler SC, Silbermann K, Wiese M. Phenyltetrazolyl-phenylamides: Substituent impact on modulation capability and selectivity toward the efflux protein ABCG2 and investigation of interaction with the transporter. Eur J Med Chem 2016;124:881-95.

159. Köhler SC, Vahdati S, Scholz MS, Wiese M. Structure activity relationships, multidrug resistance reversal and selectivity of heteroarylphenyl ABCG2 inhibitors. Eur J Med Chem 2018;146:483-500.

160. Gujarati NA, Zeng L, Gupta P, Chen ZS, Korlipara VL. Design, synthesis and biological evaluation of benzamide and phenyltetrazole derivatives with amide and urea linkers as BCRP inhibitors. Bioorg Med Chem Lett 2017;27:4698-704.

161. Li XQ, Wang L, Lei Y, Hu T, Zhang FL, et al. Reversal of P-gp and BCRP-mediated MDR by tariquidar derivatives. Eur J Med Chem 2015;101:560-72.

162. Gao Y, Shi W, Cui J, Liu C, Bi X, et al. Design, synthesis and biological evaluation of novel tetrahydroisoquinoline derivatives as P-glycoprotein-mediated multidrug resistance inhibitors. Bioorg Med Chem 2018;26:2420-7.

163. Peña-Solórzano D, Scholler M, Bernhardt G, Buschauer A, König B, et al. Tariquidar-Related Chalcones and Ketones as ABCG2 Modulators. ACS Med Chem Lett 2018;9:854-9.

164. Teodori E, Dei S, Bartolucci G, Perrone MG, Manetti D, et al. Structure-Activity Relationship Studies on 6,7-Dimethoxy-2-phenethyl1,2,3,4-tetrahydroisoquinoline Derivatives as Multidrug Resistance Reversers. ChemMedChem 2017;12:1369-79.

165. Li Y, Woo J, Chmielecki J, Xia CQ, Liao M, et al. Synthesis of a new inhibitor of breast cancer resistance protein with significantly improved pharmacokinetic profiles. Bioorg Med Chem Lett 2016;26:551-5.

166. Liao M, Chuang BC, Zhu Q, Li Y, Guan E, et al. Preclinical absorption, distribution, metabolism, excretion and pharmacokinetics of a novel selective inhibitor of breast cancer resistance protein (BCRP). Xenobiotica 2018;48:467-77.

167. Ma Y, Wink M. The beta-carboline alkaloid harmine inhibits BCRP and can reverse resistance to the anticancer drugs mitoxantrone and camptothecin in breast cancer cells. Phytother Res 2010;24:146-9.

168. Spindler A, Stefan K, Wiese M. Synthesis and Investigation of Tetrahydro- $\beta$-carboline Derivatives as Inhibitors of the Breast Cancer Resistance Protein (ABCG2). J Med Chem 2016;59:6121-35.

169. Ranjbar S, Firuzi O, Edraki N, Shahraki O, Saso L, et al. Tetrahydroquinolinone derivatives as potent P-glycoprotein inhibitors: design, synthesis, biological evaluation and molecular docking analysis. Medchemcomm 2017;8:1919-33.

170. Ranjbar S, Khonkarn R, Moreno A, Baubichon-Cortay H, Miri R, et al. 5-Oxo-hexahydroquinoline derivatives as modulators of P-gp, MRP1 and BCRP transporters to overcome multidrug resistance in cancer cells. Toxicol Appl Pharmacol 2019;362:136-149.

171. Stefan K, Schmitt SM, Wiese M. 9-Deazapurines as Broad-Spectrum Inhibitors of the ABC Transport Proteins P-Glycoprotein, Multidrug Resistance-Associated Protein 1, and Breast Cancer Resistance Protein. J Med Chem 2017;60:8758-80.

172. Schmitt SM, Stefan K, Wiese M. Pyrrolopyrimidine Derivatives as Novel Inhibitors of Multidrug Resistance-Associated Protein 1 (MRP1, ABCC1). J Med Chem 2016;59:3018-33.

173. Wang S, Wan NC, Harrison J, Miller W, Chuckowree I, et al. Design and synthesis of new templates derived from pyrrolopyrimidine as selective multidrug-resistance-associated protein inhibitors in multidrug resistance. J Med Chem 2004;47:1339-50.

174. Dantzic D, Noel P, Merien F3, Liu DX, Lu J et al. The Effects of Synthetically Modified Natural Compounds on ABC Transporters. Pharmaceutics 2018; 10:pii:E127.

175. Schäfer A, Köhler SC, Lohe M, Wiese M, Hiersemann M. Synthesis of Homoverrucosanoid-Derived Esters and Evaluation as MDR Modulators. J Org Chem 2017;82:10504-22.

176. Rho JR, Lee HS, Sim CJ, Shin J. Gagunins, highly oxygenated diterpenoids from the sponge Phorbas sp. Tetrahedron 2002;58:9585-91.

177. Cramer J, Kopp S, Bates SE, Chiba P, Ecker GF. Multispecificity of drug transporters: probing inhibitor selectivity for the human drug efflux transporters ABCB1 and ABCG2. ChemMedChem 2007;2:1783-8.

178. Schwarz T, Montanari F, Cseke A, Wlcek K, Visvader L, et al. Subtle Structural Differences Trigger Inhibitory Activity of Propafenone Analogues at the Two Polyspecific ABC Transporters: P-Glycoprotein (P-gp) and Breast Cancer Resistance Protein (BCRP). ChemMedChem 2016;11:1380-94.

179. Kim BS, Lee K, Jung HJ, Bhattarai D, Kwon HJ. HIF-1 suppressing small molecule, LW6, inhibits cancer cell growth by binding to calcineurin b homologous protein 1. Biochem Biophys Res Commun 2015;458:14-20.

180. Song JG, Lee YS, Park JA, Lee EH, Lim SJ, et al. Discovery of LW6 as a new potent inhibitor of breast cancer resistance protein. Cancer Chemother Pharmacol 2016;78:735-44.

181. Teodori E, Dei S, Floriddia E, Perrone MG, Manetti D, et al. Arylamino Esters As P-Glycoprotein Modulators: SAR Studies to Establish Requirements for Potency and Selectivity. ChemMedChem 2015;10:1339-43.

182. Orlandi F, Coronnello M, Bellucci C, Dei S, Guandalini L, et al. New structure-activity relationship studies in a series of N,Nbis(cyclohexanol)amine aryl esters as potent reversers of P-glycoprotein-mediated multidrug resistance (MDR). Bioorg Med Chem 2013;21:456-65.

183. Dei S, Braconi L, Trezza A, Menicatti M, Contino M, et al. Modulation of the spacer in N,N-bis(alkanol)amine aryl ester heterodimers led to the discovery of a series of highly potent P-glycoprotein-based multidrug resistance (MDR) modulators. Eur J Med Chem 2019;172:7194.

184. Teodori E, Dei S, Garnier-Suillerot A, Gualtieri F, Manetti D, et al. Exploratory chemistry toward the identification of a new class of multidrug resistance reverters inspired by pervilleine and verapamil models. J Med Chem 2005;48:7426-36.

185. Martelli C, Coronnello M, Dei S, Manetti D, Orlandi F, et al. Structure-activity relationships studies in a series of N,N-bis(alkanol)amine 
aryl esters as P-glycoprotein (Pgp) dependent multidrug resistance (MDR) inhibitors. J Med Chem 2010;53:1755-62.

186. Dei S, Coronnello M, Floriddia E, Bartolucci G, Bellucci C, et al. Multidrug Resistance (MDR) reversers: high activity and efficacy in a series of asymmetrical N,N-bis(alkanol)amine aryl esters. Eur J Med Chem 2014;87:398-412.

187. Polli JW, Wring SA, Humphreys JE, Huang L, Morgan JB, et al. Rational use of in vitro P-glycoprotein assays in drug discovery. J Pharmacol Exp Ther. 2001; 299:620-8.

188. To KK, Poon DC, Wei Y, Wang F, Lin G, et al. Vatalanib sensitizes ABCB1 and ABCG2-overexpressing multidrug resistant colon cancer cells to chemotherapy under hypoxia. Biochem Pharmacol. 2015,97:27-37.

189. D'Cunha R, Bae S, Murry DJ, An G. TKI combination therapy: strategy to enhance dasatinib uptake by inhibiting Pgp- and BCRPmediated efflux. Biopharm Drug Dispos. 2016;37:397-408.

190. Fan YF, Zhang W, Zeng L, Lei ZN, Cai CY et al. Dacomitinib antagonizes multidrug resistance (MDR) in cancer cells by inhibiting the efflux activity of ABCB1 and ABCG2 transporters. Cancer Lett. 2018; 421:186-98.

191. Zhang W, Fan YF, Cai CY, Wang JQ, Teng QX et al. Olmutinib (BI1482694/HM61713), a novel epidermal growth factor receptor tyrosine kinase inhibitor, reverses ABCG2-mediated multidrug resistance in cancer cells. Front Pharmacol. 2018; 9:1097. 